\title{
PROGRAMMING AND CONCEPTUAL DESIGN USING BUILDING INFORMATION MODELING
}

\author{
A Thesis \\ presented to \\ the Faculty of California Polytechnic State University, \\ San Luis Obispo
}

\author{
In Partial Fulfillment \\ of the Requirements for the Degree \\ Master of Science in Architecture
}

\author{
by \\ Mary-Alice Avila \\ January 2009
}




\section{(C) 2009 \\ Mary-Alice Avila \\ ALL RIGHTS RESERVED}




\section{COMMITTEE MEMBERSHIP}

TITLE:

AUTHOR:

DATE SUBMITTED:

COMMITTEE CHAIR:

COMMITTEE MEMBER:

COMMITTEE MEMBER:
Programming and Conceptual Design Using Building Information Modeling

Mary-Alice Avila

January 2009
Arthur J. Chapman, Professor

Architecture and Environmental Design

James Doerfler, Professor

Architecture and Environmental Design

Robert Kitamura, Executive Director

Facilities Planning \& Capital Projects 


\section{ABSTRACT \\ Programming and Conceptual Design Using \\ Building Information Modeling}

Mary-Alice Avila

This thesis explores the benefits of using Building Information Modeling (BIM) during the programming and conceptual design phase of a project. The research was based on a case study undertaken dealing with the decisions and assumptions made during the design phases of the Center for Science at Cal Poly San Luis Obispo. The project team used a traditional approach to project plan development. The finding of this study was that the project process would have greatly benefited utilizing BIM tools and a collaborative team approach in the programming and conceptual design phase. Because decisions made early in the project have enormous implications to aesthetics and cost, the increase in analysis of design options afforded by the use of BIM tools would have minimized inaccurate, incomplete and unreliable information, and allowed the design team to work in a more efficient, collaborative manner transmitting through all phases of the project.

Keywords: Building Information Modeling, BIM, architectural programming, basic assumption models, Center for Science, conceptual design, cost model, collaborative team, construction industry, integration, project feasibility, project plan development, project procedures, repository of information 


\section{ACKNOWLEDGMENTS}

First of all, I would like to thank Professor Art Chapman for his unique coaching and enthusiasm. He guided, encouraged and inspired me every step of the way through graduate school and through my thesis. Special thanks to Professor Jim Doerfler for his continued encouragement over the years and letting me try my hand at teaching by guest lecturing in his class; to Bob Kitamura for believing in me and continually coaxing me along; and to Joel Neel, who persistently cajoled me to reach for the light at the end of the tunnel and finish this endeavor.

There are many others to sincerely thank, including those who gave of their time for interviews; Dane Dodd-Hansen, Mark Miller, Joel Neel, Kimon Onuma, Chris Pechacek, Brent Pilgrim, Barbara Queen, Johan Uyttewaal and Rex Wolf, I appreciate your insights.

To my fellow graduate students for their friendship, enthusiasm and encouragement, Jenny Ferguson, Bewketu Kassa, and Eileen Joseph with a special thanks to Jenny for editing my initial work.

Rishon, thanks for sharing your college years with me, Tuesday lunches and my hopes and dreams for graduate school. Alyse, thanks for putting up with my schedule and seeing me through college. Stuart, my best friend, I owe much of my successes to you and your calm approach to life. Thanks for trusting that I could take on one more copious task and get it done. 


\section{TABLE OF CONTENTS}

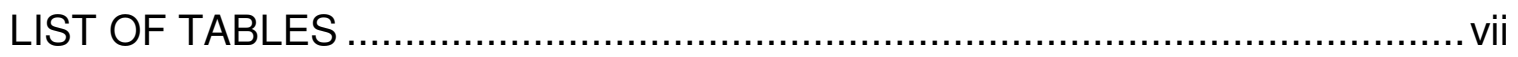

LIST OF FIGURES .................................................................................... vii

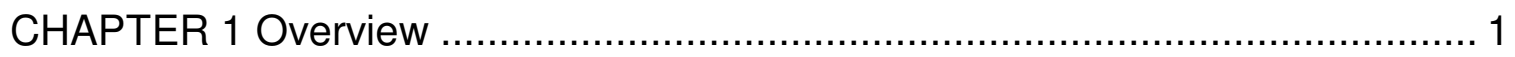

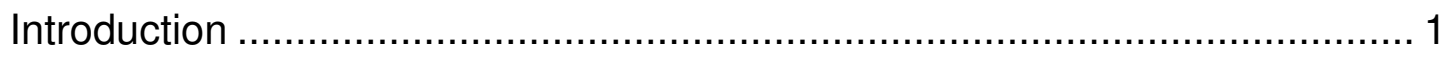

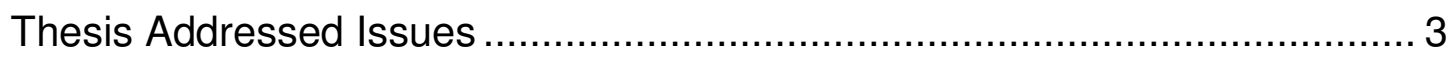

Summary of Industry-wide Issues .......................................................... 4

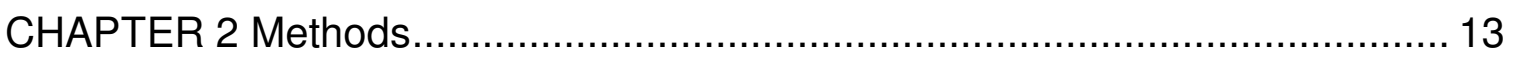

Industry Project Procedures ................................................................. 13

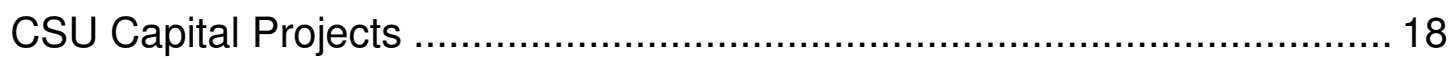

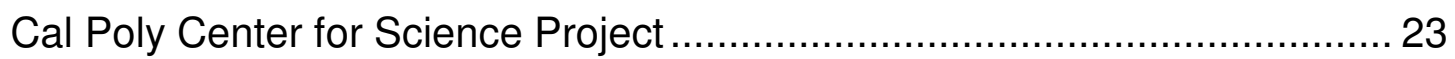

CHAPTER 3 Justification, Assumptions and Recommendations....................... 49

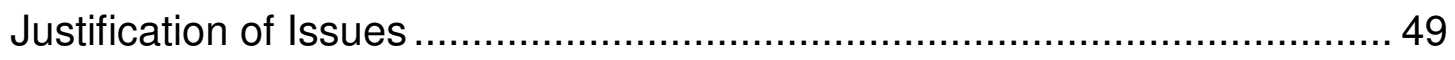

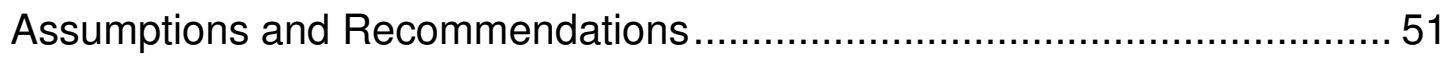

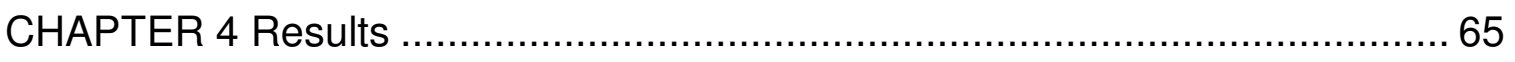

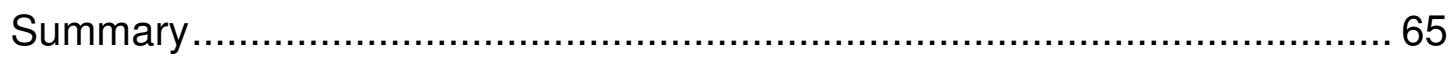

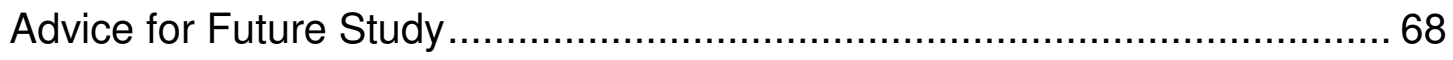

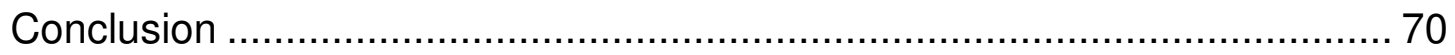

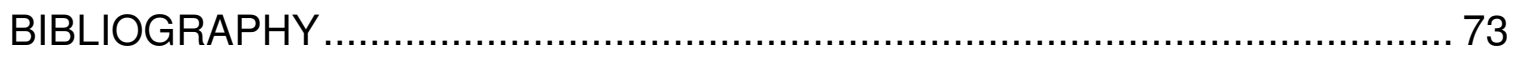

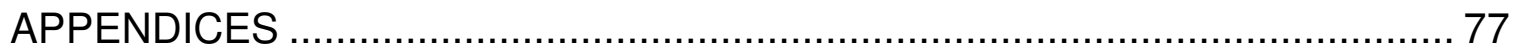

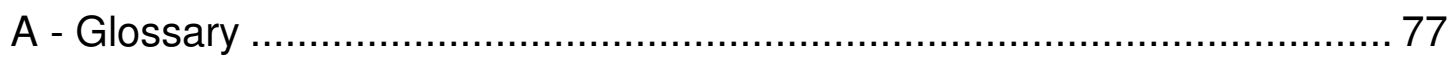

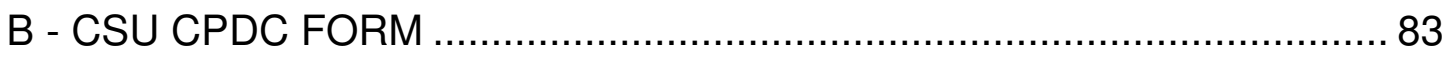




\section{LIST OF TABLES}

Table

1. Typical Project Team Participants ................................................ 14

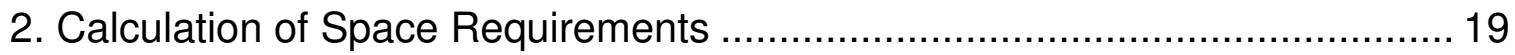

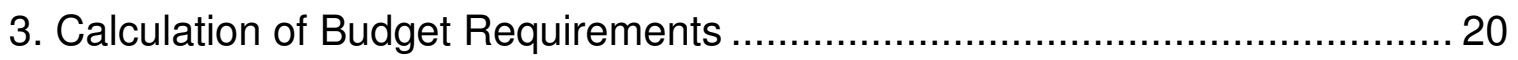

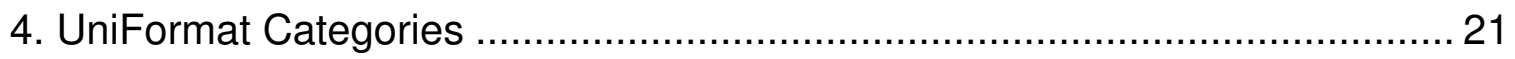

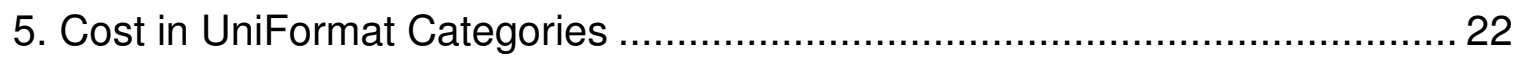

6. Programming Phase Allowable Costs versus Estimates ........................... 30

7. Cost Estimates at Programming \& Feasibility Study Phase ....................... 32

8. Cost Estimates at Schematic Design Phase........................................ 34

9. Cost Estimates at Design Development Phase ................................ 36-37

10. Cost Estimates at Construction Documents Phase .............................. 39

11. Difference between Budget and Construction costs ............................ 41

12. List of Information Provided by Cal Poly to Program Architect .................. 53

13. List of CSU CPDC Forms to Provide to Program Architect...................... 57

14. List of Program Architect Information to Provide to Design Architect ......58-59 


\section{LIST OF FIGURES}

Figure $\quad$ Page

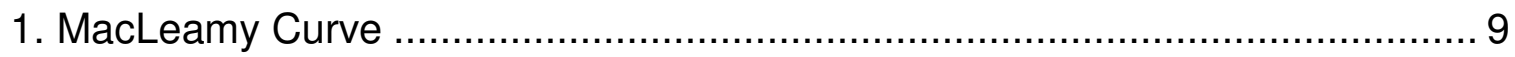

2. The Project Team, Typical.................................................................... 14

3. Construction Manager as Contractor (CMc) …........................................ 15

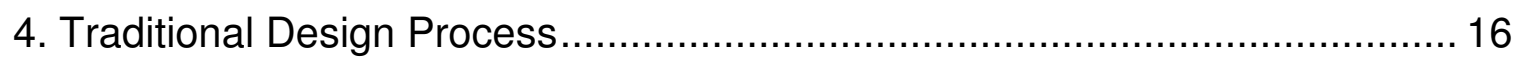

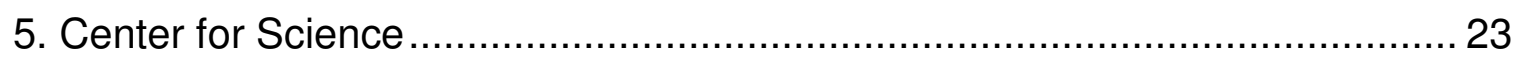

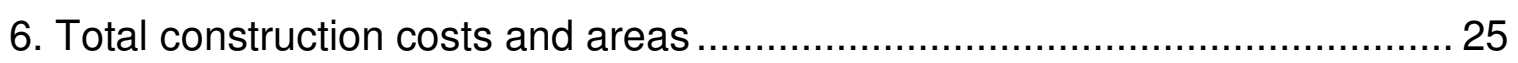

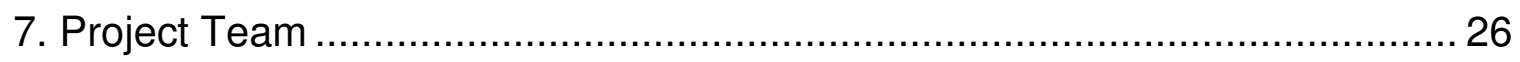

8. Center for Science Project Team........................................................... 28

9. Center for Science - Building Elevations ..................................................... 38

10. Cost Changes Over Time by Building Systems ........................................ 40

11. Cost Changes Over Time by Phase …................................................... 42

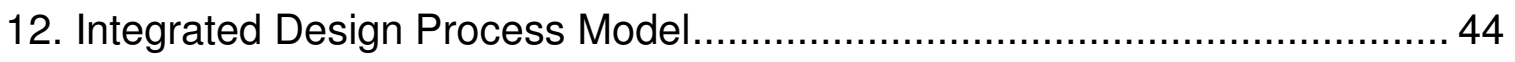

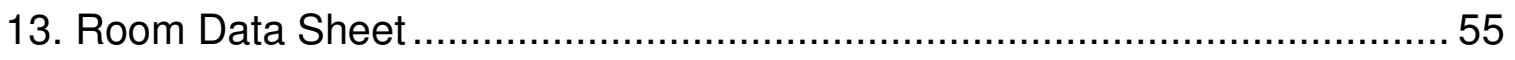

14. Basic Assumption Model - Data Base with Room Data Sheet Information..... 56

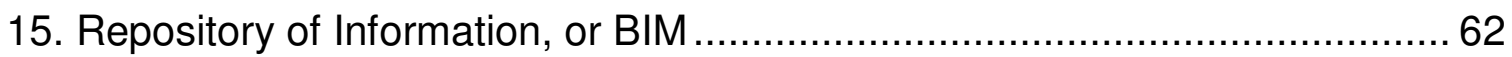




\section{CHAPTER 1}

\section{Overview}

\section{Introduction}

Planning, design and construction are moving toward a major change propelled by new tools in building information modeling (BIM). ${ }^{1}$ BIM is rapidly changing how the construction industry does business and how people work with each other. It has already begun to be used by architecture and engineering firms to prepare plans for construction, and its use is expanding to more project phases. With one of the major benefits being integrated project delivery, the goal of this thesis is to determine the benefits anticipated in initiating BIM at the programming and conceptual design phase," and to allow owners, users, architects, engineers, consultants and contractors to better understand the impacts of early decisions on a project through schematic design, design development, construction documents, construction, occupancy and deconstruction. $^{\dagger}$

Just as web-based project management software has improved efficiency and accountability in the construction phase, and is now widely accepted and used in the industry; web-based building information modeling can transform the programming and design phase as is done using Onuma Planning System (OPS) software developed by Onuma, Inc. ${ }^{2}$ Prior to the use of web-based project management, architects, engineers, construction managers, contractors,

"Conceptual Design Phase - Cal Poly requires its program architects to go beyond the normal programming effort and produce an "initial concept" according to Joel Neel, Associate Director in Facilities Planning and Capital Projects. Referred to as the "conceptual design," this "initial concept," or stacking and massing diagrams, based on the programming information, show building form, floor plans for each level, site circulation, and relationships to adjacent buildings and spaces. (Joel Neel 7 January 2009)

${ }^{\dagger}$ Project phases following the programming phase. 
subcontractors and owners each kept logs of the various documents (change orders, requests for information, submittals, change order requests, etc.), and generally only one person would have the latest, updated information. Logs were shared by photocopying and distribution with updates once or twice a month. With web-based project management, any team member with access rights, a computer and an internet portal can have the latest information any time within minutes. Additionally, each person is alerted automatically when they need to perform a task. A similar function occurs in web-based building information modeling but with the development of the building physical model.

Another way to look at web-based building information modeling is to consider it as a web-based design charette with the players proposing ideas and expanding upon ideas proposed by other players, and each testing preliminarily "what if" scenarios. This process might occur over a period of perhaps a few weeks instead of several months.

In addressing building information modeling, this thesis will be limited to the programming and conceptual design phase of a project including the available information, its analysis, and how it affects building outcomes. Finith Jernigan has observed that many architects "make too many decisions at the wrong time, with too little information." ${ }^{3}$ This thesis will look for areas where better information, presented earlier, may have changed the building outcome. In addition, it will contrast the standard approach to programming and project development versus an approach using building information modeling to program and develop the project.

By making the costing activity an integrated part of programming and moving it into the third stage where alternate blocking and stacking or three-dimensional schemes are developed, it is anticipated that some of the difficulties experienced in the development of the project may be avoided. The Center for Science at California Polytechnic State University (Cal Poly) in San Luis Obispo, California will be used as a case study. As part of that case study, viewing costing information in conjunction with alternate three-dimensional schemes will enhance 
the early analysis, and allow the owner, architect and engineers to make a more informed decision in choosing conceptual design alternatives for the project.

Finally this thesis will conclude that using BIM in at least the programming phase and conceptual phase of an architectural project can have significant advantages in time and cost savings and quality of product.

\section{Thesis Addressed Issues}

This thesis will address the following issues:

- The process and procedural changes necessary in the programming and conceptual design phase (for connecting the project team members and affecting increased efficiency) given that BIM is changing how the construction industry's delivers and shares information.

- The benefits and difficulties of using BIM in the programming and conceptual design phase.

- The anticipated outcomes--similarities and differences--of using current procedures versus BIM for the case study Cal Poly Center for Science.

- Future areas for study.

This thesis will not deal with the various construction delivery models, "nor show the effect BIM will have on them. However, some models such as Construction Manager at Risk and Design-Build, which involve the constructors early in the design and construction cycle, could derive more benefit by active participation in BIM.

"Also referred to as the "project delivery method." Each delivery method can have variations; Construction Manager at Risk is a variation on the Construction Manager method. Refer to glossary. 


\section{Summary of Industry-wide Issues}

\section{History and Developments in Process and Tools}

\section{Design Process - Master Builder, A/E with Consultants, Collaborative Teams}

Many of the buildings in Europe from the Renaissance Period were designed, engineered and built under the direction of one person, the master builder. "Hundreds of years ago, all of architecture could be held in the intelligence of a single maker, the master builder, part product and building engineer, and part material scientist, the master builder integrated all the elements of architecture in a single mind, heart, and hand."

As buildings became larger and taller, new materials and building systems, such as structural, mechanical, electrical and plumbing were developed, requiring special engineering knowledge. As noted by Paul Seletsky in an interview by Bryant Rousseau, "Traditionally, we've had a very linear process in the way we practice architecture." ${ }^{5}$ Consultants were brought in when and as needed, usually after the architect had completed the schematic design (site plan, floor plan, and elevations). Keeping the consultants segregated with the architect doing all of the coordination did not cause major problems. Usually minor changes were made to the plans to accommodate the systems.

As buildings become more complex with the addition of more systems, uses, equipment, codes, regulations, standards and laws, the segregated approach resulted in deficiencies in the architectural process. Structural, plumbing, mechanical, electrical, communication and fire systems collided, while user needs and code requirements were missed. Users moved into spaces that did not live up to their expectations. Owners were faced with changes that became more costly as the project progressed. In Refabricating Architecture, the authors, both architects, point out that the "current architecture production is typified by stratification of the various components used in design and implementing a

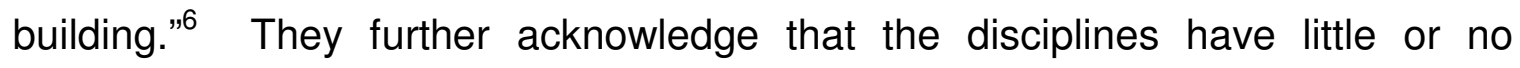
communication, and the benefit of their "collective intelligence" never makes it past the hierarchy into the project. ${ }^{7}$ It is interesting to note that collaborative 
teams of designers and builders are used in other industries, such as automobile and aircraft industries, working together in an integrated and productive manner. ${ }^{8}$ For the construction industry to move forward, an integrated process will need to be adopted industry-wide.

Design Tools - Hand Drafting, CAD, BIM

Among the first documentation of architectural plans and specifications (or in this case, list of materials) in the United States was by Thomas Jefferson in planning his home, Monticello in Virginia. ${ }^{9}$ Similar hand drafting, using t-square, triangles and pencil on paper continues even today.

The use of CAD and word processing, which promised to revolutionize plans and specifications development and coordination between disciplines, never materialized. For example, AutoCAD operators tend to be among the least experienced persons working on a project, adding to the problems discovered during the construction phase. In discussing the ways in which architecture has failed to take advantage of new technologies, Kieran and Timberlake note: "The architecture industry's move from T-Square and linen to computer as a means of documentation has essentially been only a switch in media." ${ }^{\prime 10}$ Computers can be used for so much more than just 2-D representations. Other industries, such as aircraft and automobile, provide examples.

In the aircraft industries, airplanes are initially built and maintained as threedimensional (3-D) models including non-graphical attributes about each component. After an airplane is constructed, the 3-D model and component attributes are maintained. ${ }^{11}$

The term "Building Information Model (BIM)" was coined in early 2002, but has been used by some firms for more than 20 years, according to Kimon $G$. Onuma. $^{12}$ Leaders like Onuma are beginning to engage others in learning, trying and using BIM. Ask architects about the acceptance and use of BIM in the construction industry and those using it will state full use can be expected in about 3-5 years. ${ }^{13}$ Those not yet experiencing its use, such as Robert Kitamura, Director of Facilities and Planning at Cal Poly San Luis Obispo, estimate it will 
take 15 years to become fully integrated. ${ }^{14}$ This validates comments by Mike Kenig, Vice Chairman of Holder Construction Company, in his interview with Bailey Webb that BIM users estimate five years or less, while non-users estimate ten years. ${ }^{15}$

\section{BIM}

\section{$2 D$ and $3 D C A D$ versus $B I M$}

Two- and three-dimensional (2D and 3D) computer aided drawing (CAD) programs enable the drafter to use a computer to create drawings representing data as geometric entities with points, lines, rectangles, circles, polygons and planes. The nature of the data, however, limits it use as it does not contain information that indicates walls, floor, ceiling and the physical space. In order to see a wall in elevation, more lines must be drawn. In order to perform cost estimating or an energy analysis on the room, several calculations must be done. Simply put, the wall does not know it is a wall, and the space created by the walls does not exist as a physical area in a CAD program.

In BIM, information is represented as object-based building data models. Lachmi Khemlani, in "The IFC Building Model: A Look Under the Hood," explains:

A data model in any given domain describes the attributes of the entities in that domain as well as how these entities are related to each other. Since all computer programs deal with some kind of data, they must have some kind of underlying data model. Traditional 2D CAD and generic 3D modeling programs internally represent data using geometric entities such as points, lines, rectangles, planes, etc. ${ }^{16}$

For example, a room may be represented (drawn) as a rectangle with length and width defined as well as its point of origin ( $X$ and $Y$ coordinate location on the drawing). CAD models then are inadequate for their lack of representation of real world scenarios as noted by Khemlani:

Thus, while these applications can accurately describe geometry in any domain, they cannot capture domain-specific information about the entities. In the case of the AEC industry, technological progress has been severely constrained by the limited intelligence of such applications in representing buildings and being able to extract the relevant information from the 
representation that is needed for design, analysis, construction management, operation, and so on.

To overcome the limitation of general-purpose geometric representations, every design-related industry has been developing and using object-based data models that are specific to their domain. In the case of the building industry, this translates to a data model that is built around building entities and their relationship to one another. ${ }^{17}$

For instance, a room is represented (drawn) using walls with length, depth, height, type, connection to other walls, attached spaces with function, occupant and area, and with a starting point ( $\mathrm{X}$ and $\mathrm{Y}$ coordinate location on the drawing)

The interrelationship of objects is vital in creating a more realistic interpretation of a building. Khemlani further explains that the geometry used in $2 D$ and $3 D$ is merely "one of the properties." The building model can be viewed in plan, elevation, section or detail without drawing more lines. In other words, the wall knows it is a wall, the space a space, and the floor a floor. This allows the model to be created, viewed and altered in plan, elevation, section and detail with changes automatically updated for all views allowing the designer to see the implications of changes immediately. For example, move an exterior wall two feet out and the walls perpendicular to it lengthen and remain attached to it in plan, elevation, section and detail views. There is no need to "re-draw" the corresponding views.

BIM has further advantage as information about the building can be extracted from BIM and used to analyze, document, or visualize a building. Software programs used with BIM can extract information and analyze cost, energy, egress, code compliance, etc.

\section{Project Information}

The holistic nature of BIM provides significant opportunities for all members of the building team. For example, team members with access can be aware of all changes being made in real time-a substantial information sharing and coordinating opportunity. BIM can allow information created in the programming and conceptual design phase to be carried throughout subsequent phases with information being added or modified as the project progresses. BIM can reduce errors made by the design and construction team members by checking for 
conflicts in the drawings, such as a pipe penetrating a duct; and a duct cutting through a critical structural member. It can free-up time spent on schedules, such as door and window, by creating dynamic schedules that update automatically as changes are made. It can be used to provide such analysis as daylight and energy usage simulations to aid in the design, and cost estimates for building systems to aid in decision making.

\section{Using BIM in Conceptual Design Phase}

Given that the conceptual design decisions set the building's function, general appearance and cost, and are carried throughout the project to completion and occupancy; it would be more efficient and advantageous to begin rigorously implementing BIM from the initial start of a project so that all project information, including options, decisions and costs, are documented and shared with the building team members. "Decisions are often made in the programming phase of a project that have enormous downstream implications-for aesthetics, cost, energy consumption, and the ultimate suitability of a building for its intended purpose-on the basis of inaccurate, incomplete, or unreliable information." ${ }^{19}$ It is at this point that various massing models, systems and assemblies can be considered. When tied to a cost estimating model, the design team can quickly see the relationship between initial design assumptions and cost. Initiating BIM at this phase creates additional substantial potential for efficiencies.

At the conceptual design phase, as many options as possible should be considered, as well as their cost impacts. Because these early decisions will be carried throughout the project, owners, architects, engineers and consultants will rely on them. It is far easier to scale back the project early in the design process than to continuously look for areas to cut costs in future phases as later changes become increasingly expensive to implement and have less value. The American Institute of Architects (AIA) reiterated the power of the focus on the early design phase when laying out Integrated Project Delivery (IPD) principles, noting that "integrated projects are uniquely distinguished by highly effective collaboration . . . commencing at early design." ${ }^{20}$ In redefining project team procedures, the AIA suggests "moving design decisions upstream as far as 
possible to where they are more effective and less costly." This is illustrated by the MacLeamy Curve (Figure 1). In the IPD process, "conceptualization (expanded programming)" includes greater cost detail than in a conventional project. ${ }^{21}$ Costs linked to BIM and detailed by systems allow a better understanding of the cost ranges and importance of each system. The focus can then be directed to areas where improvements and costs have a larger impact.

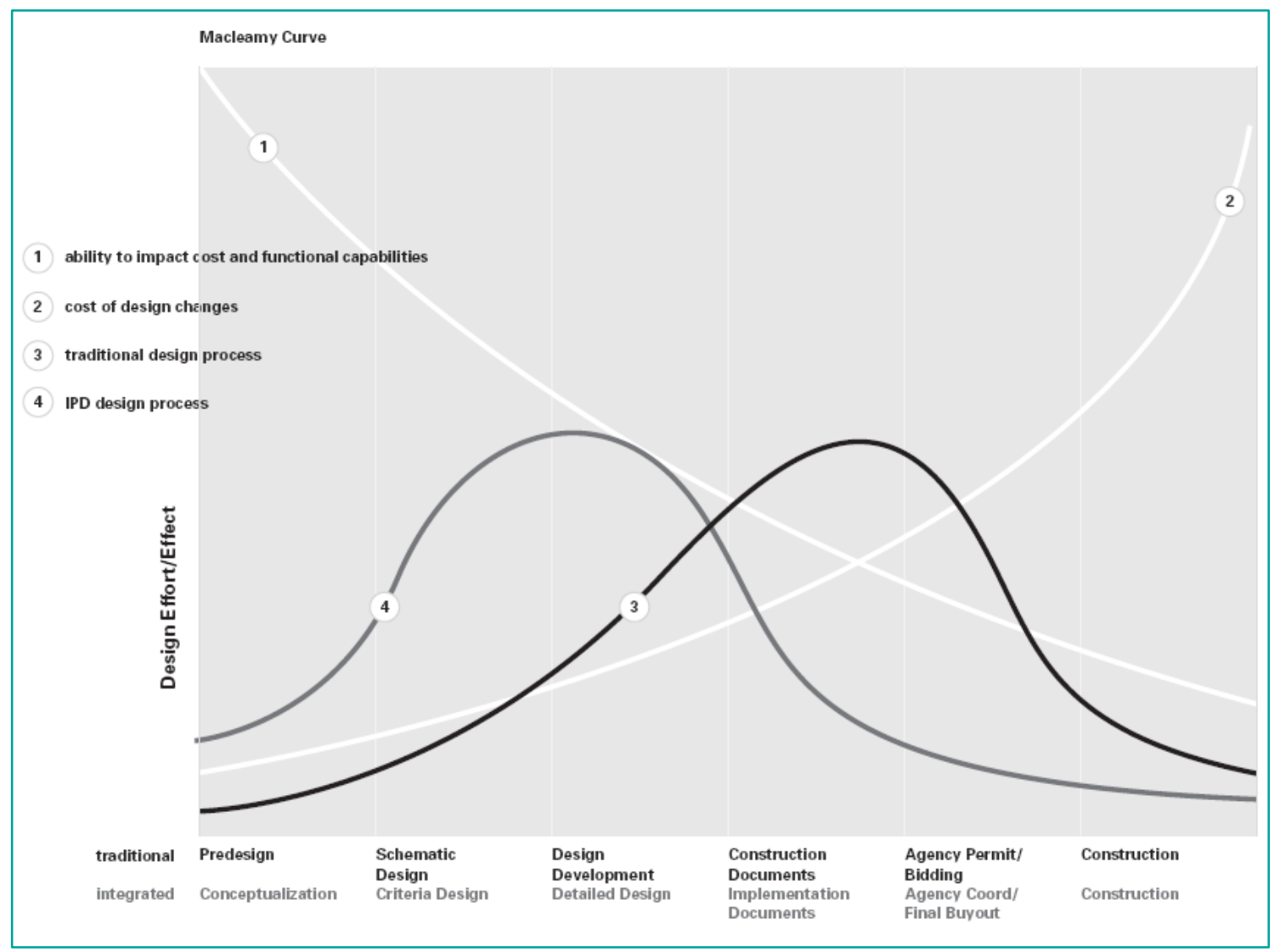

Figure 1. MacLeamy Curve. Source: Graph from AIA National / AIA California Council, Integrated Project Delivery: A Guide, version 1 (The American Institute of Architects, 2007), table page 21.

\section{Interoperability and Integration}

The Role of Interoperability

To work in a fully integrated manner, the software applications used by each project team member must be able to share data seamlessly. To do so requires a non-proprietary object-based building data model used by all software vendors. Software interoperability will enable those involved in project design, construction, management and deconstruction to work in an integrated process. 
"Software interoperability is seamless data exchange at the software level among diverse applications, each of which may have its own internal data structure." ${ }^{22}$ It is suggested that when owners, designers, engineers and constructors collaborate by sharing a common database, projects will evolve more quickly, complex projects will be doable, and project costs more manageable.

Current Issues with IFC

The International Alliance for Interoperability (IAI), which facilitates interoperability in the construction industry, has created the IFC (Industry Foundation Classes), the common language for software. Khemlani states, "The IFC model is intended to support interoperability across the individual, disciplinespecific applications that are used to design, construct, and operate buildings by capturing information about all aspects of a building throughout its lifecycle."23

There are several object-based building data model applications currently being used in the industry. These include Graphisoft's ArchiCAD and Autodesk's Revit, in addition to hybrid applications such as, Bentley Architecture based on MicroStation, and Autodesk Architectural Desktop based on AutoCAD. However, as Lachmi Khemlani in "The IFC Building Model: A Look Under the Hood" notes "these are applications by commercial vendors and their internal data models are proprietary." 24 As she explains, this is why one software program cannot share its information with another without the use of specific translators. In other words, they do not speak the same language and cannot communicate. Sharing data from one of these software applications with other software, such as a Microsoft Excel spreadsheet, is impossible, or at best, extremely difficult. Integration and interoperability are the keys to information sharing.

\section{Time and Money}

Currently, when architects, engineers, and cost estimators need certain project information embedded in a software program, they must first retrieve the data needed and then re-enter it into their specific software analysis program. Translating the information back to the drawing stage takes the same effort, and therefore, testing many building configuration options is time intensive and cost 
prohibitive on most projects. BIM offers the potential for fully integrated systems for all users.

Using the IFC model to capture building information, commercial building-model based applications can exchange data with each other quickly and accurately. Instead of spending time to enter and check data, and then re-enter it again, project team members can put more design time into project space and detail development, and can test more options with the goal of creating more effective and efficient design and engineering solutions.

'Jeff Yoder, "Further Down the Merry Road to BIM," Building Design and Construction (1 November 2007). http://www.bdcnetwork.com/article/CA6501465.html (accessed 11 December 2007).

${ }^{2}$ Onuma, Inc., "Onuma Planning System," under "Products," http://www.onuma.com (accessed 5 February 2008).

${ }^{3}$ Finith Jernigan, BIG BIM little bim (Salisbury: 4Site Press, 2007), 19.

${ }^{4}$ Stephan Kieran and James Timberlake, Refabricating Architecture (New York: McGraw-Hill, 2004), xi-xiii.

${ }^{5}$ Bryant Rousseau, "The ArchRecord Interview: SOM's Carl Galioto and Paul Seletsky on BIM," Architectural Record (2008), http://aec.cadalyst.com/aec/Column\%3A+1-2-3+Revit/1-2-3Revit-BIM-and-Visualization-Part-1/ArticleStandard/Article/detail/438584?contextCategoryld+ 6569 (accessed 26 November 2007).

${ }^{6}$ Kieran and Timberlake, 12.

${ }^{7}$ Kieran and Timberlake, 12.

${ }^{8}$ Kieran and Timberlake, 9-11.

${ }^{9}$ I.T. Frary, Thomas Jefferson Architect and Builder (Richmond: Garrett and Massie, 1939), 5.

${ }^{10}$ Kieran and Timberlake, 58.

${ }^{11}$ Kieran and Timberlake, 59.

${ }^{12}$ Kimon Onuma, Forward, BIGBIM little bim (Salisbury: 4Site Press, 2007), 3.

${ }^{13}$ Kimon Onuma and Yong Ku Kim, "BIMStorm LAX - Overview and Players' Perspectives." (5 February 2008), Webinar.

${ }^{14}$ Robert Kitamura, interview by author, San Luis Obispo, CA, 2008.

${ }^{15}$ Bailey Webb, "BIM dream becoming a reality," Atlanta Business Chronicle (July 6, 2007), http://www.bizjournals.com/Atlanta/stories/2007/07/09/focus7.html (accessed 10 January 2009).

${ }^{16}$ Lachmi Khemlani, "The IFC Building Model: A Look Under the Hood," AECbytes (30 March 2004), http://www.aecbytes.com/feature/2004/IFCmodel.html (accessed 13 February 2008). 
${ }^{17}$ Khemlani IFC.

${ }^{18}$ Khemlani IFC.

${ }^{19}$ Michael Tardif, "Architect Creates Design Synthesis Software," AlArchitect - The American Institute of Architects (17 August 2007), http://www.aia.org/aiarchitect/thisweek07/0/17/ 0817rc_face.dfm (accessed 18 February 2008).

${ }^{20}$ AIA National / AIA California Council, Integrated Project Delivery: A Guide, version 1, (The American Institute of Architects, 2007), Sub-title page.

${ }^{21} \mathrm{AIA} I P D, 24$.

${ }^{22}$ National Institute of Building Sciences (NIBS), Facility Information Council (FIC), National Building Information Modeling Standard, Version 1 - Part 1: Overview, Principles, and Methodologies (2007), 7.

${ }^{23}$ Khemlani, IFC.

${ }^{24}$ Khemlani, IFC. 


\section{CHAPTER 2}

Methods

Before proposing changes in the methods used to develop programming and conceptual design studies, current industry procedures were examined in order to lay the foundation for the case study of the Cal Poly Center for Science project. Additionally, to understand the expectations for administration of the project, CSU policies and procedures were reviewed and documented.

\section{Industry Project Procedures}

\section{Standard Model}

The typical project team composition and the predesign* process are the framework for the CSU process. In this section, the construction delivery method selected for the Center for Science is defined. Lastly, to understand the goals of Programming during the predesign phase, the programming process is outlined.

\section{Project Team}

"The construction of a facility is the culmination of the collective needs, ideas, talents, and services of a diverse group of individuals." These individuals can be classified into four basic teams as shown in Table 1, or separate participant groups, organized to conceive, design and build a project (Figure 2). These separate teams of owner, designer, contractor and supplier are brought into the project during the particular phases as dictated by the type of delivery method. For example, in the Design-Bid-Build method, contractors join the project team at the Construction Phase. In the $\mathrm{CM}$ at Risk method, the contractor joins the project team usually after the Schematic Phase.

*Programming, concept and feasibility. 
Table 1. Typical Project Team Participants

\begin{tabular}{|c|c|c|c|c|}
\hline Teams & Owner & Design & Contractor & Supplier \\
\hline $\begin{array}{l}\text { Team } \\
\text { Participants }\end{array}$ & $\begin{array}{l}\text { - Owner } \\
\text { - Facility Manager } \\
\text { - Facility } \\
\text { Maintenance } \\
\text { Engineer } \\
\text { - Construction } \\
\text { Manager } \\
\text { - Tenant } \\
\text { - Facility User }\end{array}$ & $\begin{array}{l}\text { - Architect / } \\
\text { Engineer } \\
\text { - Interior Designer } \\
\text { - Specifier } \\
\text { - Construction } \\
\text { Contract } \\
\text { Administrator } \\
\text { - Specialty } \\
\text { Consultant }\end{array}$ & $\begin{array}{l}\text { - Contractor } \\
\text { - Contractor's } \\
\text { Project Manager } \\
\text { - Construction } \\
\text { Manager } \\
\text { - Superintendent } \\
\text { - Subcontractor(s) }\end{array}$ & $\begin{array}{l}\text { - Manufacturer's } \\
\text { Employee } \\
\text { - Independent } \\
\text { Project } \\
\text { Representative } \\
\text { - Distributor / } \\
\text { Supplier }\end{array}$ \\
\hline
\end{tabular}

Source: Data from The Construction Specifications Institute, The Project Resource Manual - CSI Manual of Practice, Fifth Edition, (McGraw-Hill, 2005) Figure page 1.2.

\section{The Project Team Typical}

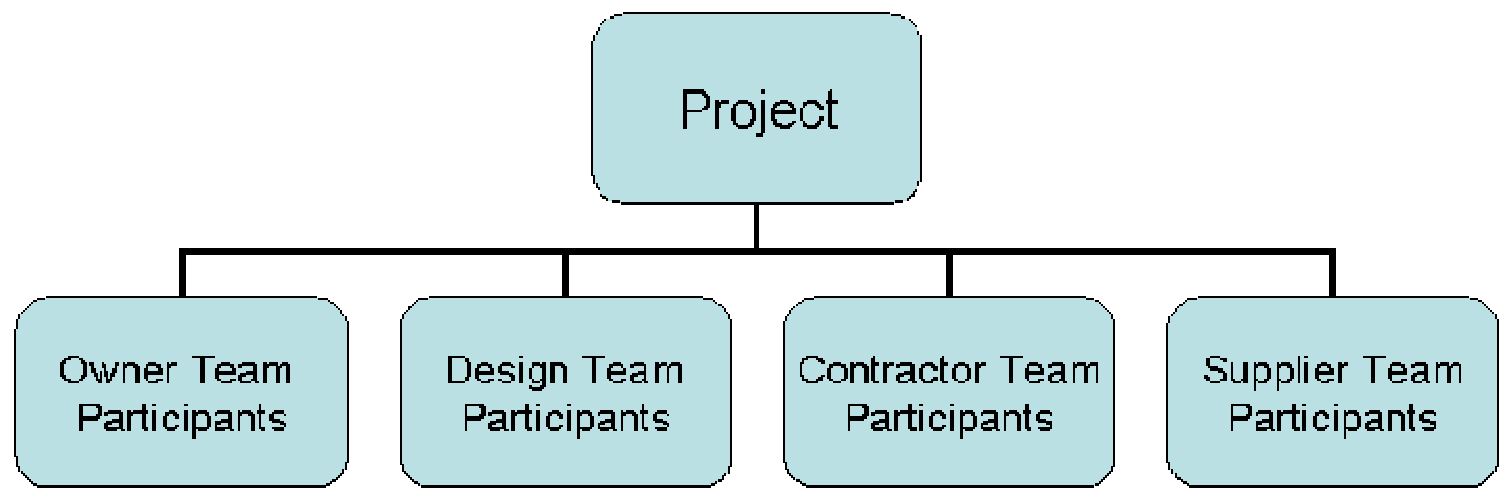

Figure 2. The Project Team, Typical. Source: Data adapted from The Construction Specifications Institute, The Project Resource Manual - CSI Manual of Practice, Fifth Edition, (McGraw-Hill, 2005) Figure page 1.2. 
Construction Delivery Method - Construction Manager as Contractor

In the Construction Manager as Contractor (CMc) construction delivery method, also referred to as "at-risk construction management," the "CMc is responsible for the completed project and bears the financial risk in the same manner as a contractor." 2 As with other delivery methods, the contractor and the architect each have a direct contract with the owner, but not with each other (Figure 3). They are, however, required to communicate and work together to accomplish the project.

\section{Construction Manager as Contractor (CMc)}

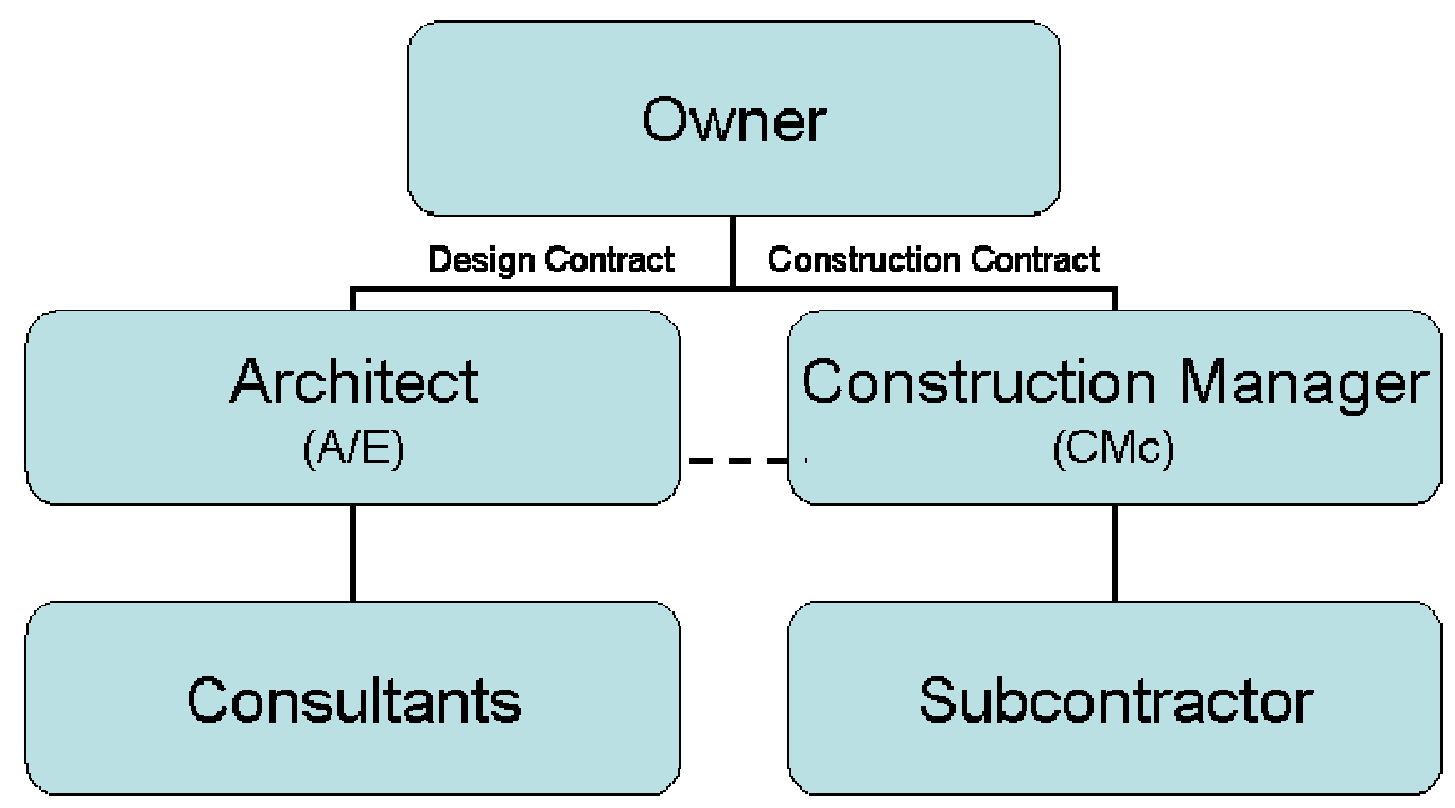

Note: A solid line indicates a contract or purchase order, a dashed line indicates communication.

Figure 3. Construction Manager as Contractor (CMc). Source: Data from The Construction Specifications Institute, The Project Resource Manual - CSI Manual of Practice, Fifth Edition, (McGraw-Hill, 2005) Figure page 3.24. 


\section{Traditional Predesign Process}

In the traditional predesign process, the Architect does not usually involve their Design Consultants (civil, structural, mechanical, electrical, plumbing, controls, special, etc.) in programming or predesign. Quite often, the first time Design Consultants see a project is in the Schematic Design Phase, and in some cases, not fully until the Design Development Phase. In the traditional design-bid-build project delivery method, Constructors (contractors) and Sub-constructors (subcontractors) are not involved until the construction phase, and actually obtain their first look at the project during the Bidding Phase. Each party's involvement in the project phases is illustrated by Figure 4.

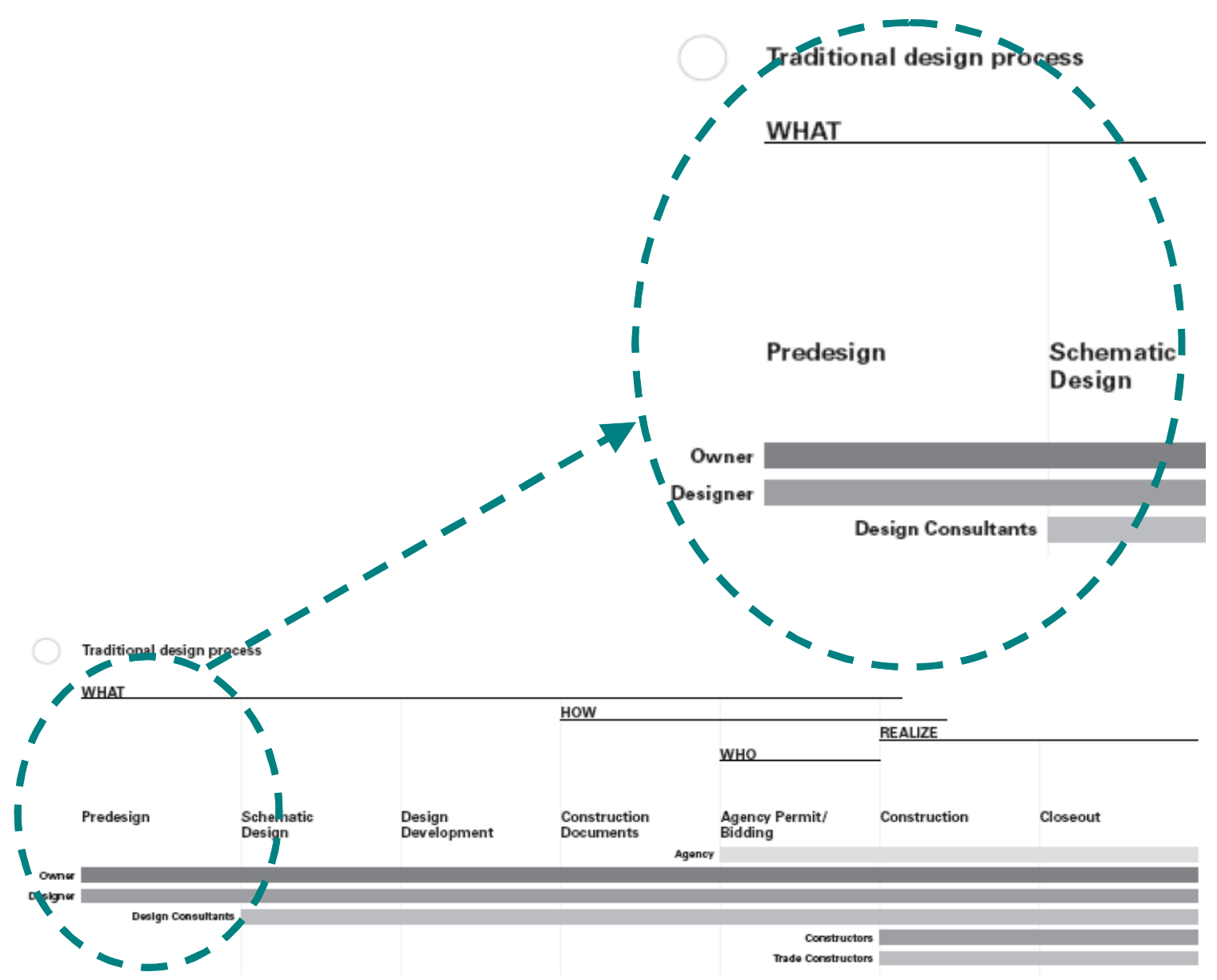

Figure 4. Traditional Design Process. Source: Data from AIA National / AIA California Council, Integrated Project Delivery: A Guide, version 1 (The American Institute of Architects, 2007), table page 22. 


\section{Defining Programming}

The Dictionary of Architecture and Construction defines a program as:

A statement prepared by or for an owner ... setting forth the conditions and objectives for a building project including its general purpose and detailed requirement, such as a complete listing of the rooms required, their sizes, special facilities, etc. ${ }^{3}$

Programming is generally approached in a similar manner by most architects regardless of the size or complexity of the building. In the standard model, a building project begins with an idea. For example, the owners or users realize they have outgrown their current facilities and need to expand incorporating newer technology and working processes. The architect is asked to look at current operations and functions, help the users organize their thoughts about how they would like to work, and development a program. In defining what constitutes the planning process leading to the program, the authors of From Problem Seeking search for "sufficient information to clarify, to understand, to state the problem." 4 Furthermore, they have formalized the programming process into a five step, linear procedure:

Goals - Project Goals, including Mission, Goals and Objectives, and Policies; Operational Goals

Facts - Staffing requirements, User Description, Evaluation of Existing Facility, Site Analysis, Climate Analysis, Zoning Regulations, Code Survey, Cost Parameters, Project Delivery Schedule

Concepts - Organizational Structure, Functional Relationships, Priorities, Narrative Functional Descriptions, Operational Concepts

Needs - Space Requirements, Parking Requirements, Land Requirements, Project Phasing, Budget Analysis for Renovation and New Construction Problem Statements - Design Problem, Operational Problem 5 


\section{CSU Capital Projects}

To better understand the policies, procedures and nuances of projects in the CSU system, and the documentation required to submit for and receive funding approval, the CSU model was studied with an eye toward recognizing areas where information can be contained within and required forms generated from the BIM. For instance, if the campus student population and existing classroom information were held within the BIM, it could be used to generate additional space and associated funding requirements.

\section{CSU Model}

The California State University (CSU) requires each of its twenty-three campuses to develop a Capital Outlay Program that anticipates and plans for student enrollment utilizing "proper planning, programming, budgeting and project administration," and State policy requires all capital outlay projects be "carefully conceived and justified to provide cost effective solutions for program delivery." Campuses are responsible for the initial planning, cost benefit analysis and feasibility studies needed to submit a proposed project to the CSU for funding. The results of these efforts - plans (site and individual room), outline specifications (equipment, furnishings, special requirements by room) and cost estimate-are used in preparing the CSU submission to the Board of Trustees for the proposed capital outlay program. ${ }^{7}$

\section{Campus Square Footage Requirements}

First, each campus calculates the space requirements to accommodate the projected full-time equivalent (FTE) students on the campus resulting in an assignable square footage (ASF) entitlement. The existing ASF is subtracted from the entitlement to determine the additional space needed. The example in Table 2 illustrates a portion of the CSU Form CPDC 2-3 used to calculate the additional space for a fictitious lecture and teaching lab on a CSU campus. 
Table 2. Calculation of Space Requirements

\begin{tabular}{|c|c|c|c|c|c|c|c|}
\hline $\begin{array}{l}\text { Type of } \\
\text { Instruction }\end{array}$ & $\begin{array}{c}\text { Projected } \\
\text { FTE }^{\text {a }}\end{array}$ & $\begin{array}{l}\text { Weekly } \\
\text { Student } \\
\text { Contact } \\
\text { Hrs. } / 100\end{array}$ & $\begin{array}{c}100 \\
\text { WSCH }^{b}\end{array}$ & $\begin{array}{c}\text { Standard } \\
\text { (ASF }^{c} / 100 \\
\text { WSCH) }\end{array}$ & $\begin{array}{c}\text { ASF }^{\text {c }} \\
\text { Entitle- } \\
\text { ment }\end{array}$ & $\begin{array}{l}\text { Existing } \\
\text { ASF }^{\mathrm{c}} \text { to } \\
\text { be } \\
\text { retained }\end{array}$ & $\begin{array}{c}\text { Additional } \\
\text { Space } \\
\text { Needed }\end{array}$ \\
\hline Lecture & 1500 & 0.15 & 225 & 52 & 11,700 & 1,700 & 10,000 \\
\hline $\begin{array}{l}\text { Teaching } \\
\text { Lab (LD) }\end{array}$ & 250 & 0.45 & 112.5 & 255 & 28,688 & 8,088 & 20,600 \\
\hline Subtotals & 1750 & & & & 40,388 & 9,788 & 30,600 \\
\hline
\end{tabular}

Source: Data adapted from The California State University, "Calculation of Space Requirements for Instructional Projects, Form CPDC 2-3," under "Major Capital Outlay Forms," http://www.calstate.edu/cpdc/Facilities_Planning/forms.shtml (assessed 27 May 2008).

Notes:

a Full-time Equivalent

b Weekly Student Contact Hours

c Assignable Square Feet

\section{Campus Allowable Costs}

CSU allowable costs for a project are determined by multiplying the additional space needed on a campus by a predetermined cost per square foot. The allowable cost per square foot is determined by the type and function of space found in the CSU Budget Composite Matrix (Form CPDC 2-6.5). For instance, a general classroom would have an allowance of $\$ 316$ per gross square foot, whereas a lab for science would have an allowance of $\$ 411$ per gross square foot. $^{8}$ The areas are multiplied by the respective allowance plus additional square footage for building support areas (restroom, corridors, custodial, etc.) and systems (mechanical, electrical, etc.) to arrive at the total building construction cost. Table 3 is an illustration of applying the allowance to the "additional space needed" as shown in Table 2. (For clarity, the building support areas such as stairs, elevators, restrooms, custodial, etc. are excluded.) 


\section{Table 3. Calculation of Budget Requirements}

\begin{tabular}{llrlrr}
\hline Space Type & ASF & EFF. & GSF & \$/GSF & \multicolumn{1}{c}{ BLDG. COST } \\
\hline Classroom (General) & 10,000 & $63 \%$ & 15,873 & $\$ 316$ & $\$ 5,015,873$ \\
Teaching Lab (LD) & 20,600 & $59 \%$ & 34,915 & $\$ 411$ & $\$ 14,350,169$ \\
\hline Subtotals & 30,600 & & 50,788 & & $\$ 19,366,043$ \\
\hline
\end{tabular}

Source: Data adapted from The California State University, "Budget Composite Matrix, Form CPDC 2-6.5," under "Major Capital Outlay Forms," http://www.calstate.edu/cpdc/Facilities_Planning/forms.shtml (assessed 27 May 2008).

Costs for the building site and landscaping are dependent on site conditions and vary by campus and project location. Some campuses, built on hills will have higher site costs than those built in level valleys. Accordingly, site location on the campus at Cal Poly affects the site construction costs. For instance, the Center for Science is located on the upper part of the campus core and bedrock is located near the earth's surface. Engineering III and IV are located in an area of campus that is flatter and composed of soil depth of 25 to 65 feet to bedrock. Site excavation and substructure construction are both affected by the type of soil and the depth to bedrock.

Other costs, such as fees for services are either formula driven or determined based on previous projects. These costs include design, engineering, testing, plan checking and construction management, and are known in the industry as soft costs. The hard costs for building, site and landscaping are added to the soft costs for the grand total project costs. At this point in the project process, building costs are represented by building systems organized by CSI UniFormat categories show in Table 4. 
Table 4. UniFormat Categories

\begin{tabular}{cl}
\hline Levels & \multicolumn{2}{c}{ Construction Systems and Assemblies } \\
\hline \multicolumn{1}{c}{ A SUBSTRUCTURE } & Foundations \\
A20 & Basement Construction \\
B SHELL & \\
B10 & Superstructure \\
B20 & Exterior Enclosure \\
B30 & Roofing \\
C INTERIORS & \\
C10 & Interior Construction \\
C20 & Stairs \\
C30 & Interior Finishes \\
D SERVICES & \\
D10 & Conveying \\
D20 & Plumbing \\
D30 & Heating, Ventilating, and Air \\
& Conditioning (HVAC) \\
D40 & Fire Protection \\
D50 & Electrical \\
Z GENERAL & \\
Z10 & General Requirements \\
Z20 & Contingencies \\
E10 & Equipment \\
E20 & Furnishings \\
E EQUIPMENT AND FURNISHINGS \\
F10 & Special Construction \\
F20 & Selective Demolition \\
G10 & Site Preparation \\
G20 & Site Improvements \\
B SPECIAL CONSTRUCTION AND DEMOLITION & Site Civil / Mechanical Utilities \\
Site Electrical Utilities \\
Othe
\end{tabular}

Source: Data from The Construction Specifications Institute, UniFormat ${ }^{\mathrm{TM}}$, Third Printing - January 2000 (The Construction Specifications Institute, 2007), page 20-23. 
Projected amounts are entered into the CSU Capital Outlay Estimate (Form CPDC 2-7), ${ }^{9}$ a portion of which is illustrated in Table 5 . An additional column in the Form, to the right of the total (not shown), provides a cost per gross square foot. This allows the CSU to compare costs across campuses for similar space and construction types, and campuses to monitor the cost of each system.

Table 5. Cost in UniFormat Categories

\begin{tabular}{|c|c|c|c|c|}
\hline Levels & & Systems and & Subtotal & Total \\
\hline \multicolumn{4}{|c|}{ A SUBSTRUCTURE } & $\$ 1,370,135$ \\
\hline & A10 & Foundations & $\$ 1,370,135$ & \\
\hline & A20 & Basement Construction & 0 & \\
\hline \multicolumn{4}{|c|}{ B SHELL } & $7,037,189$ \\
\hline & B10 & Superstructure & $3,088,903$ & \\
\hline & B20 & Exterior Enclosure & $2,013,886$ & \\
\hline & B30 & Roofing & $1,934,401$ & \\
\hline \multicolumn{4}{|c|}{ C INTERIORS } & $2,043,398$ \\
\hline & C10 & Interior Construction & $1,065,180$ & \\
\hline & $\mathbf{C 2 O}$ & Stairs & 0 & \\
\hline & C30 & Interior Finishes & 978,218 & \\
\hline \multicolumn{4}{|c|}{ D SERVICES } & $7,452,322$ \\
\hline & D10 & Conveying & 525,704 & \\
\hline & D20 & Plumbing & 554,035 & \\
\hline & D30 & HVAC & $2,714,693$ & \\
\hline & D40 & Fire Protection & 438,742 & \\
\hline & D50 & Electrical & $3,219,148$ & \\
\hline \multicolumn{5}{|c|}{ E EQUIPMENT AND FURNISHINGS } \\
\hline & E10 & Equipment & 0 & \\
\hline & E20 & Furnishings & 0 & \\
\hline \multicolumn{4}{|c|}{ F SPECIAL CONSTRUCTION AND DEMOLITION } & $1,462,999$ \\
\hline & F10 & Special Construction & $1,462,999$ & \\
\hline \multirow{2}{*}{\multicolumn{2}{|c|}{ F20 }} & Selective Demolition & $\mathbf{0}$ & \\
\hline & & & & $\$ 19,366,043$ \\
\hline
\end{tabular}




\section{Cal Poly Center for Science Project}

\section{Case Study}

The Center for Science was chosen as the case study for comparison of the traditional project management approach versus using building information modeling (Figure 5). It is a complex project, located in the educational core of the Campus, and presents many challenges in its design, construction and occupancy.

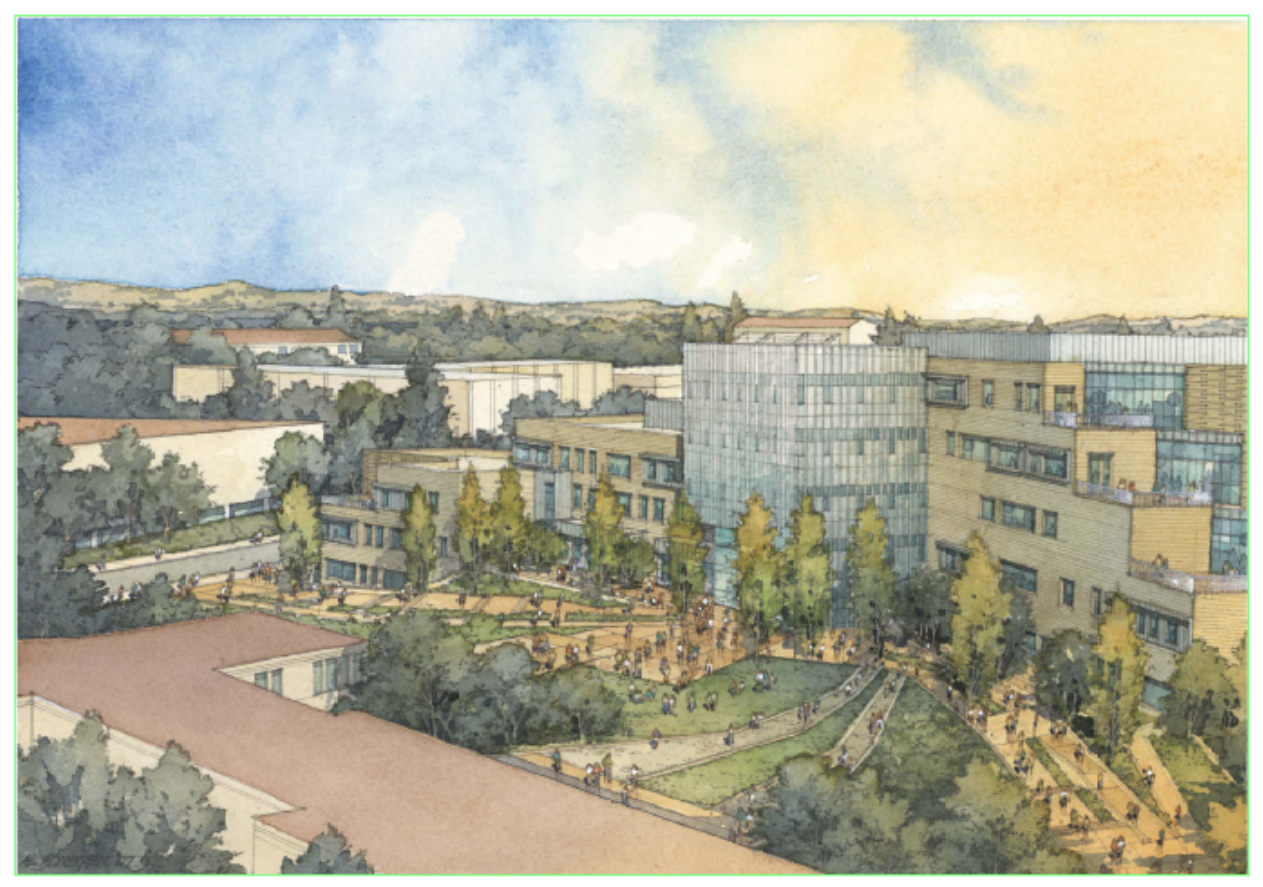

\section{CENTER FOR SCIENCE}

Figure 5. Center for Science. Source: California Polytechnic State University, San Luis Obispo, Facilities Planning and Capital Project, Center for Science Project, drawing by ZGF (16 June 2007).

This section will provide a brief history of the project, how the Project Team structure was identified, the method used to develop the project budget, an analysis of the cost estimates at each design phase, and a summary of the cost changes over time by building.

A significant difference in implementation and effectiveness was expected to be found between using the industry' traditional standard model versus using a 
Building Information Model (BIM) approach. The results highlight the need for a shift to BIM to significantly improve quality and efficiency.

\section{Study Area}

In an interview with Barbara Queen, Project Manager for the Center for Science, two negative key areas of the building design were identified as potentially benefiting from the use of BIM--the shell or exterior enclosure, and the labs and fume hoods. These two items were not significantly explored by the design team, nor were experts consulted or potential options given enough consideration during the programming through design development phases. Limited information provided the basis for the decisions on these two items. Subsequent options and future potential savings were limited and handicapped by the need to rework architectural and engineering solutions to reverse unfavorable decisions. By not having explored and carried forward potential options for these building systems, the project budget continued unresolved during the construction document phase as the project team explored potential savings in building systems.

The Center for Science case study was limited to the exterior enclosure of the building and specifically, this thesis investigates the decisions made during the three phases-Schematic, Design Development and Construction Documents. Assumptions and decisions made by the team members were documented.

\section{Project History}

The University began planning the Center for Science project in 1999. Over fourteen University groups were represented in the study. At that time, it was anticipated to include the Mathematics Department and an applied research component. However, over several years, the project scope was revised as illustrated by the graph in Figure 6 . The changes in total construction costs (by fund and square footage) submitted to the California State University (CSU) in the Capital Outlay Budget Change Proposal (COBCP) are typical of project iterations before CSU scope and funding approval is obtained. In 2005, the applied research component was removed and with a reduced scope, the project was approved and slated to receive initial funding in early $2007 .{ }^{10}$ In the interim, 
the committees and design team, originally established to work on the project, were brought together to validate the scope. ${ }^{11}$ The Center for Science, which is a replacement and growth project, is scheduled to commence construction in May 2009, after completion of the working documents phase.

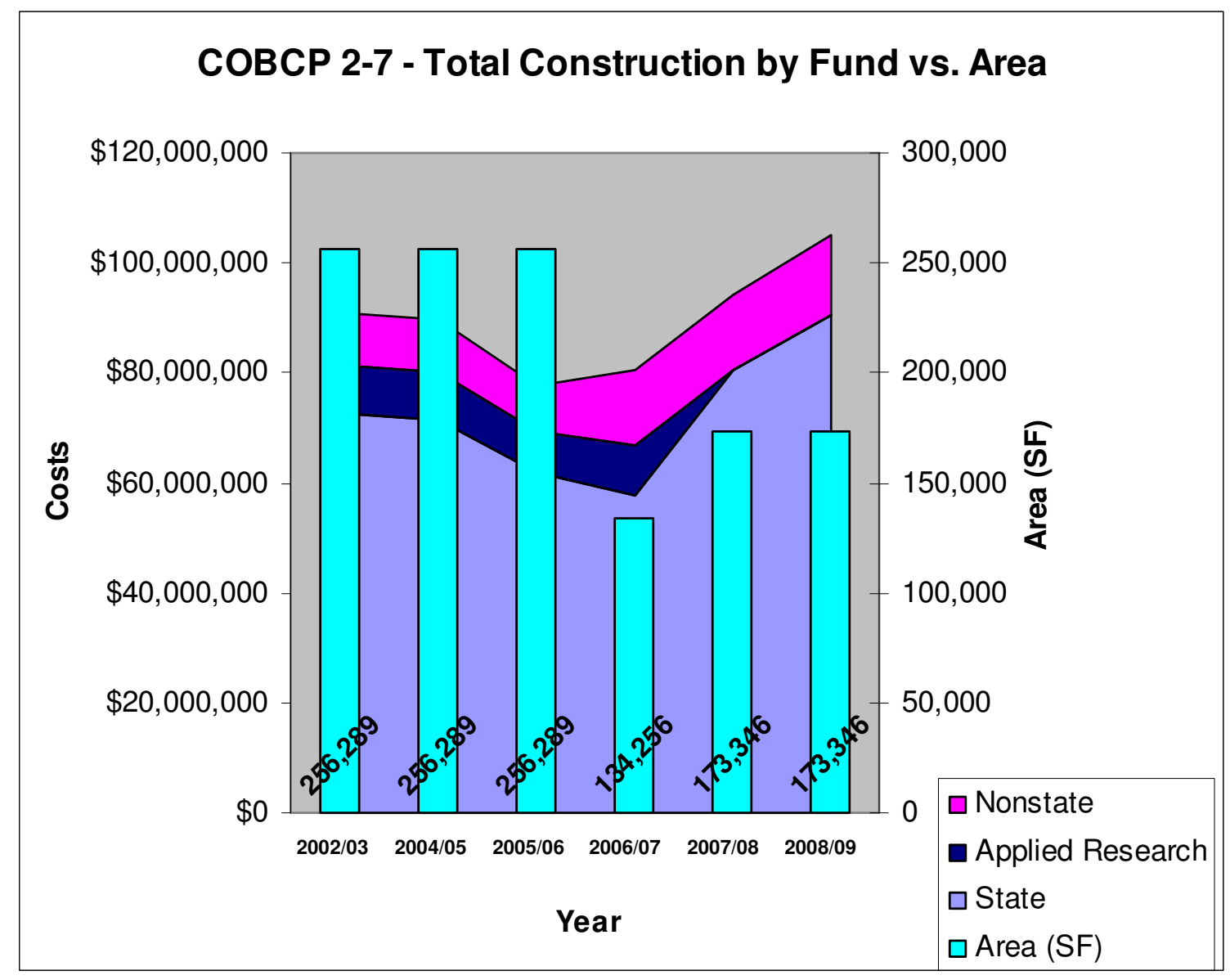

Figure 6. Total construction costs and areas. Source: Data adapted from California Polytechnic State University, COBCP, Years 2002/03, 2004/05, 2006/07, 2007/08 and 2009/10, Capital Outlay Estimates (Form CPDC 2-7). 


\section{Project Team}

In Figure 7, the Project Team organization chart exemplifies the complexity of the temporary organization established to accomplish a project within the CSU system. Unlike typical team illustrations, this organization chart is shown from the campus Project Manager point-of-view. As the owner's representative, the Project Manager is responsible for keeping all team members on track.

\section{Project Team}

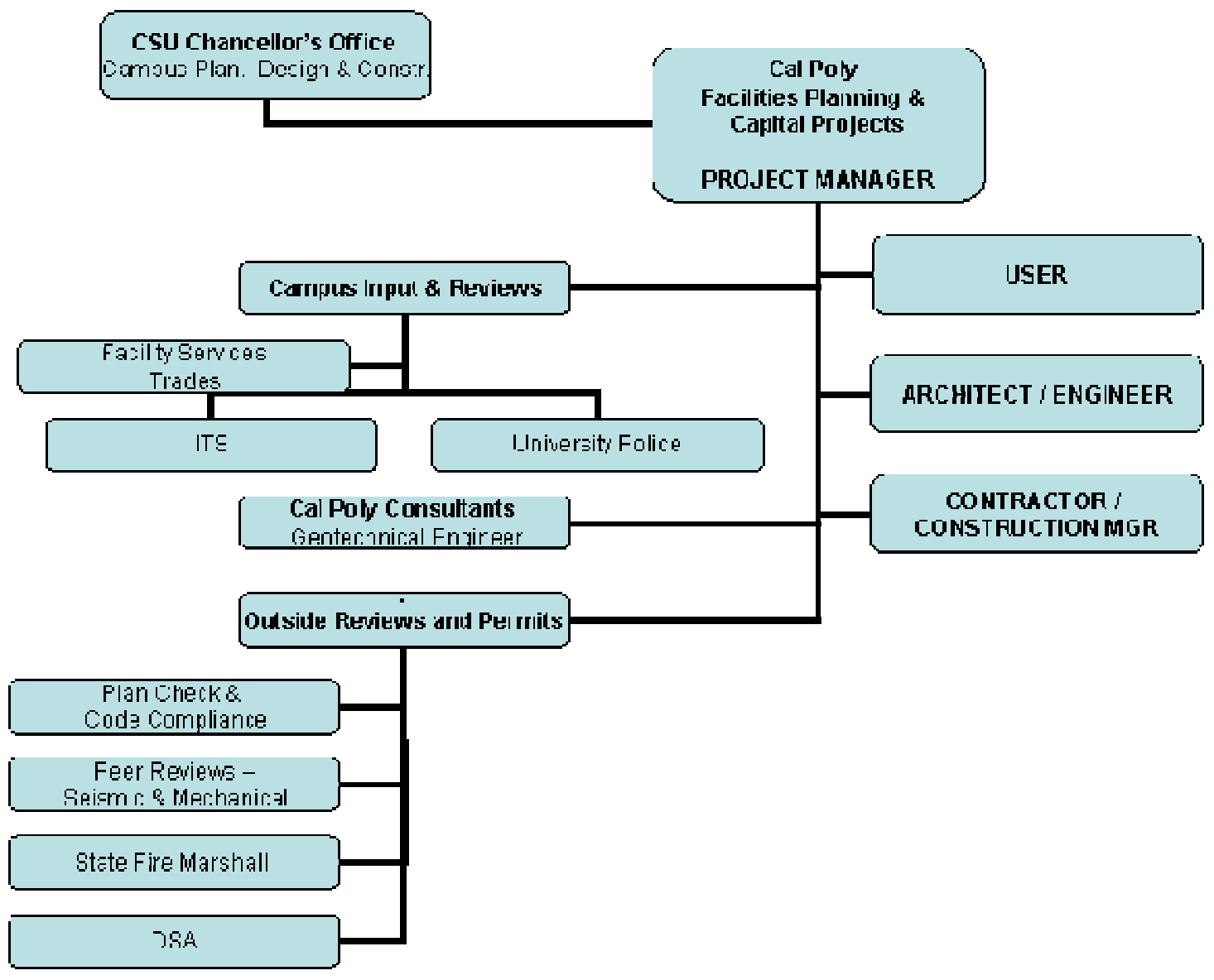

Figure 7. Project Team. Source: Data adapted from Facilities Planning \& Capital Projects. 
Cal Poly often hires one architectural firm to provide services during the Programming Phase, and later on a different firm for the Design and Construction Phases. The Program Architect for the Center for Science was RRM Design Group of San Luis Obispo, California. RRM helped Cal Poly to establish the initial scope and budget for the Center for Science project.

After the project received funding for design services, the Architect, Zimmer Gunsul Frasca Architects LLP (ZGF) of Los Angeles, California, was selected to begin work on the Schematic Design Phase. Upon completion of the Schematic Design Phase, Gilbane Building Company of San Jose, California, was selected the Construction Manager at-Risk, and brought on-board at initiation of the Design Development Phase. ${ }^{12}$ In the Center for Science Project, the Owner is represented by Cal Poly's Facilities Planning and Capital Projects Department staff. The User is the College of Science and Math led by the Dean and Associate Dean. The project team relationships with the design architect and construction manager are illustrated in Figure 8.

*In the Construction Manager at-Risk (CM at Risk) projects, the CM is issued a service agreement for the preconstruction (project design) services, and works with the architect performing value engineering, constructability reviews, cost estimating, etc. to produce the optimum project value for the money available, and complete and accurate construction documents that the $\mathrm{CM}$ can then distribute to the trade contractors to bid to secure a Guaranteed Maximum Price (GMAX). Once the CM obtains the GMAX bid, the owner enters into a construction agreement with the $\mathrm{CM}$ for the construction phase of the project. http://www.calstate.edu/BF/Newsletters/letters04-05/1104issue.pdf (accessed 07 January 2009) 


\section{Center for Science Project Team}

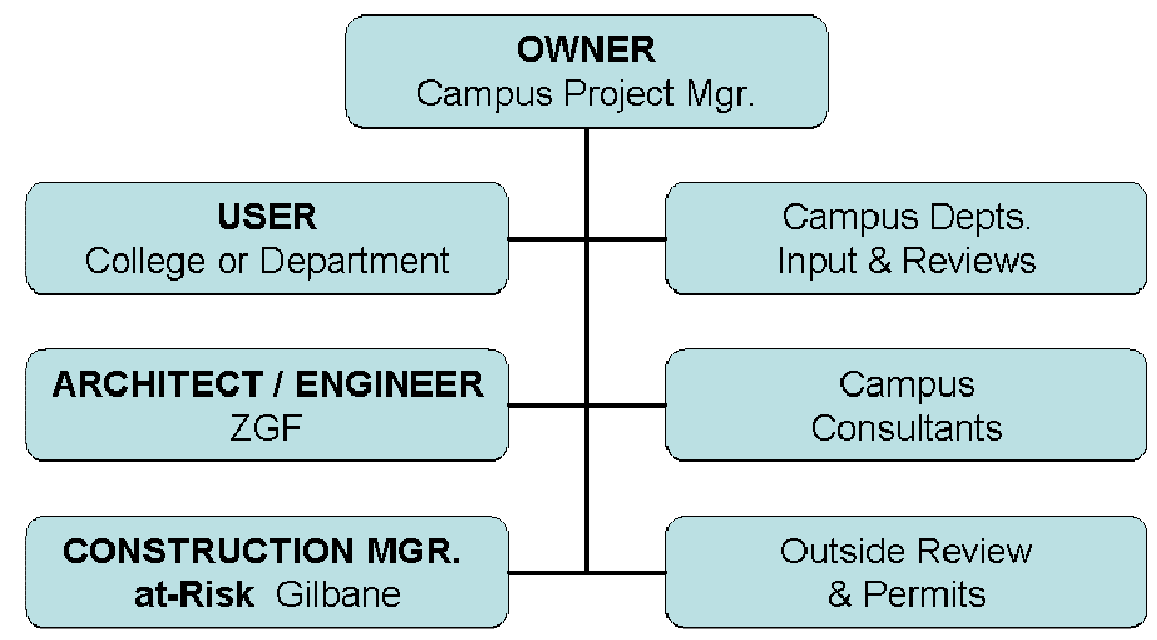

Figure 8. Center for Science Project Team. Source: Data adapted from Facilities Planning \& Capital Projects.

\section{Project Budget}

During the Programming Phase, two independent estimates were prepared and reconciled. The results were found to be above the CSU allowable costs requiring that the Program be modified. Two additional independent estimates were then prepared and reconciled with the results demonstrating that the allowable costs were inadequate for the project. ${ }^{13}$ RRM, the program architect, cautioned that areas for cost savings would need to be explored as the project moved forward, and included further recommendations to reduce costs while maintaining building performance: 1) simplified building layout to reduce envelope, 2) integrated systems design to reduce redundancy, and 3) phased implementation of the Centennial Green. ${ }^{14}$ These recommendations continued to be considered throughout project development, and long after the study was completed.

The CSU Programming budget, the results from the two final Programming Phase estimates for the building and site construction, and the final budget from 
the May 18, 2007 campus allowable costs (CSU Allocation) are listed in Table 6. The sitework construction is shown as a lump sum cost since it is considered separately from the building cost by the CSU. For purposes of consistency throughout this report, the CSU Allocation will be shown as the last, revised amount approved by the CSU on May 18, 2007, and obtained from Cal Poly Facilities Planning and Capital Projects Department. 
Table 6. Programming Phase Allowable Costs versus Estimates

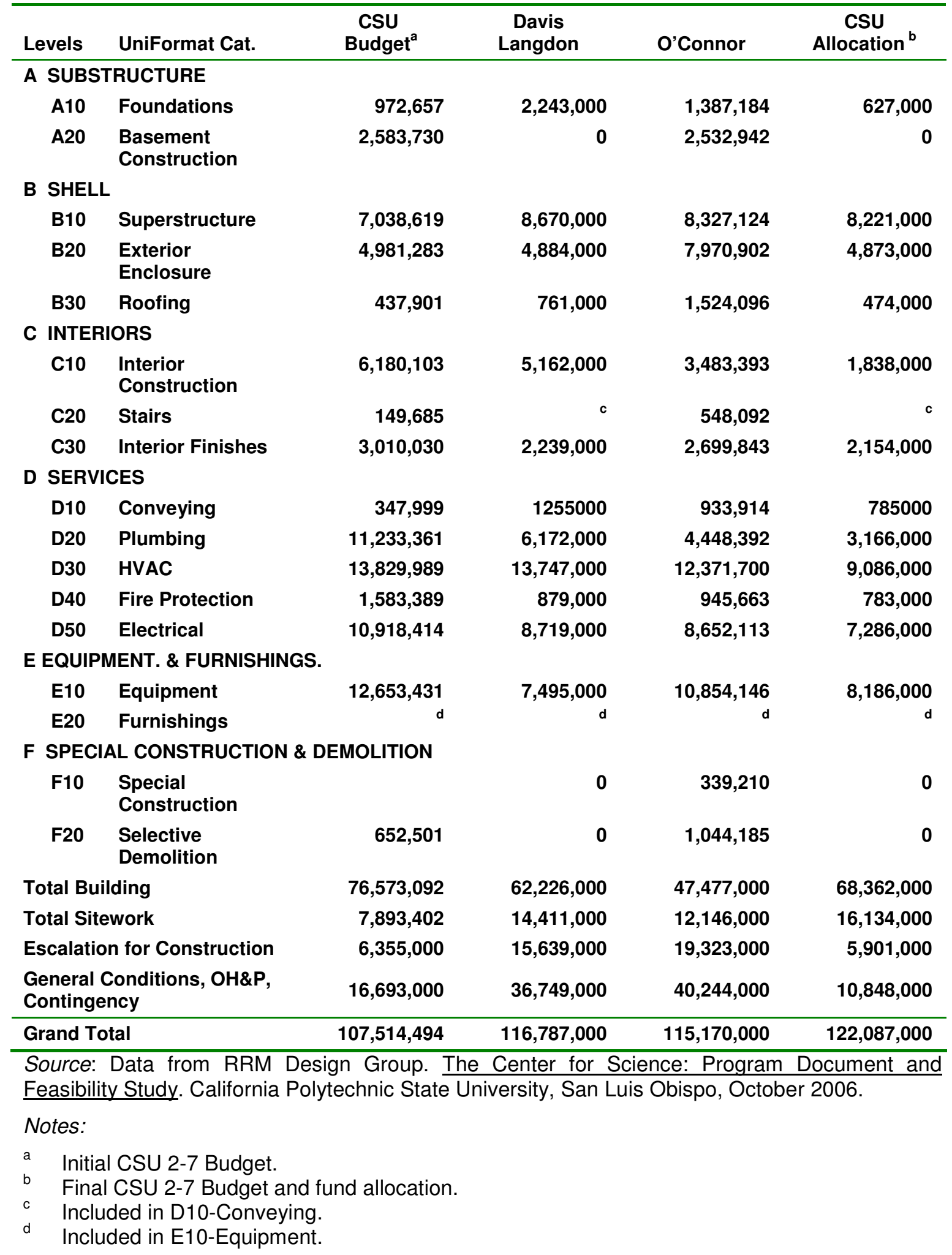




\section{Exterior Enclosure}

While the building information model assumptions will be limited to the Programming and Conceptual Design Phase, this portion of the research examined the exterior enclosure cost estimates and Basis of Design from Programming and Conceptual Design through the Construction Documents.

\section{Programming and Conceptual Design}

In the Programming and Conceptual Design Phase, independent cost estimates were prepared by two firms-Davis Langdon (the Program Architect's estimator) and O'Connor Construction Management (the University's estimator). In Table 7, the descriptions used by each estimator were compared and correlated where possible. Variations in descriptions occurred because each has a separate cost data base from which to work. Items broken-out by one may be lumped together by another. Quantities may be determined in a different manner by each. At this phase in the project, cost estimating is as much an art as it is a science in that to a large extent the information is sketchy at best. Each estimator used experience and judgment in making assumptions for inclusion and exclusion of items in preparing the estimates.

While it is interesting to note the differences between the two approaches, the two estimates are within three percent of each other-an acceptable variance. They are, however, far below the final CSU allocation of $\$ 7,970,902$, at approximately 60 percent of the allocation. Cost escalation may be a portion of the higher cost, but insufficient information at this phase would seem a more likely reason. Even taking into account a 20 percent design contingency, both estimates are still below what the project will end up costing. 
Table 7. Cost Estimates at Programming \& Feasibility Study Phase

\begin{tabular}{|c|c|c|c|c|}
\hline \multicolumn{5}{|c|}{ Summary } \\
\hline Description & Da & s Langdon & & 'Connor \\
\hline Opaque Wall Construction & $\overline{\$ \$}$ & $2,709,250$ & $\$$ & $2,841,300$ \\
\hline Exterior Glazing Systems & $\$$ & $1,680,250$ & $\$$ & $2,156,000$ \\
\hline Exterior Doors & $\$$ & 99,300 & $\$$ & 56,379 \\
\hline Miscellaneous & $\$$ & 395,500 & $\$$ & - \\
\hline Total & $\$$ & $4,884,300$ & $\$$ & $5,053,679$ \\
\hline
\end{tabular}

Variance between:

$\mathrm{DL} \& \mathrm{OC}$

$3 \%$

DL \& CSU 2-7

$63 \%$

OC \& CSU $2-7$

$58 \%$

Average DL \& OC to CSU 2-7

$60 \%$

\section{CSU 2-7 final project budget amount: $\quad \$ \quad 7,970,902$}

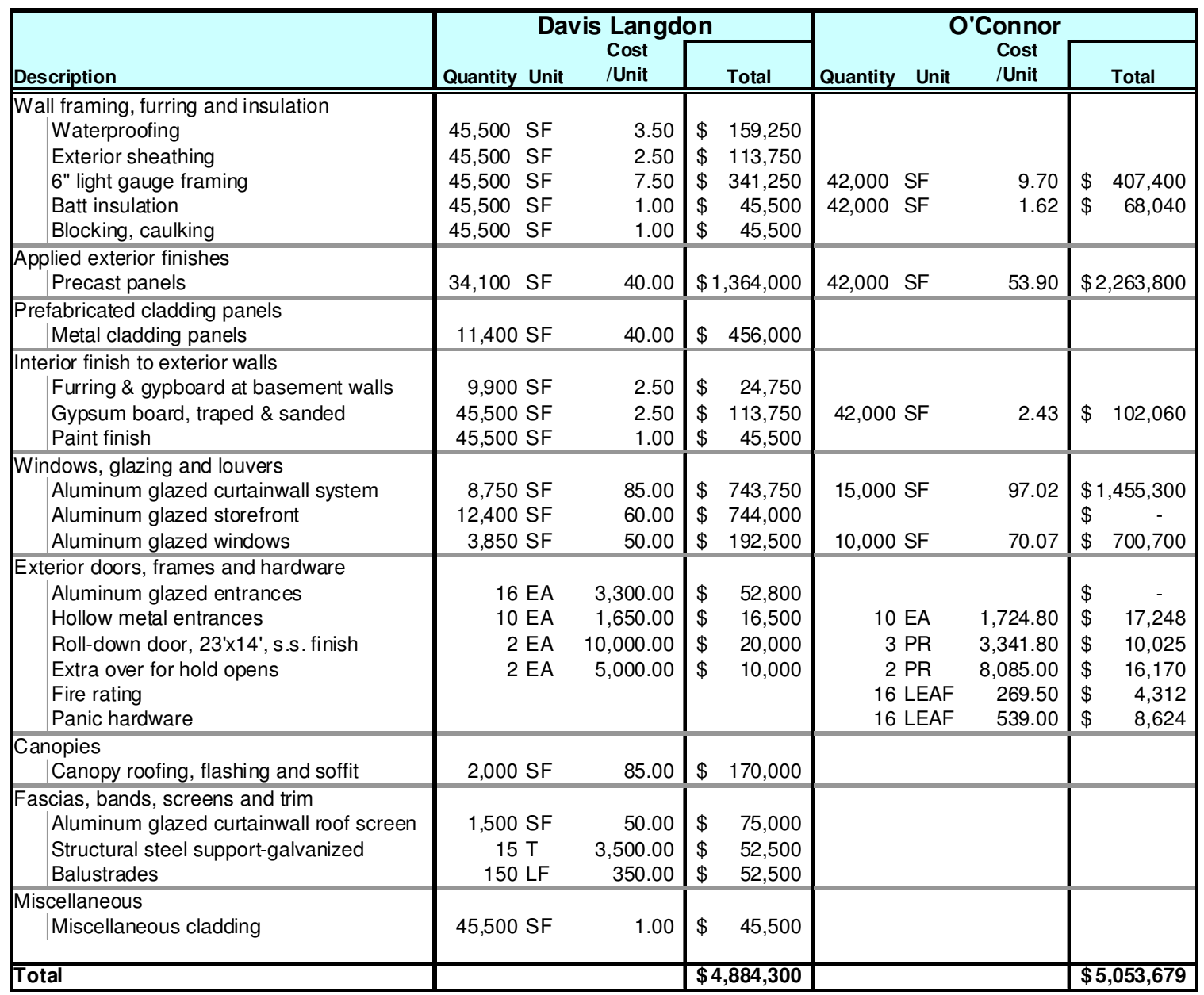




\section{Schematic Design Phase*}

In the Schematic Design Phase, independent cost estimates were prepared by Davis Langdon, the cost estimator for the design architect, ZGF, and by the construction manager, Gilbane Building Company. In organizing Table 8, the descriptions used by each estimator were compared and correlated where possible.

Two areas of disagreement in the estimates emerged - materials and quantities. It is also interesting to note that the quantities used by each estimator for the same items differ. For example, the Curtain Wall System quantities differ by 6832 square feet for concealed header/jamb and 3044 square feet for the 2" deep horizontal snap caps. The cost difference totals $\$ 1,272,340$ for these two items. Even the total number of doors is different- 40 total for Davis Langdon and 36 total for Gilbane. Several items listed by one are described differently by the other, or omitted completely. For example, the 8" CMU Penthouse Walls are not included in the Davis Langdon estimate.

At this phase in the project, the architect is attempting to hold the costs down, while the construction manager is trying to include every possible contingency. The variance between the two estimates is 31 percent. Davis Langdon is 9 percent below the final CSU allocation of $\$ 7,970,902$, and Gilbane is

19 percent above it. The average of their differences is 5 percent from the CSU allocation.

Variation in costs may be partially due to different approaches to cost data and lack of detailed information leading to different assumptions at this early phase of the project.

"Interprets the project requirements to show relationship of the facility to the site, other buildings, and the campus; exterior design of the facility; relationship of interior areas; materials to be used in construction: types of structural, mechanical, electrical, and telecommunication systems to be utilized; construction costs; and life cycle cost analysis. Documents include drawings, outline specifications and cost estimates. 
Table 8. Cost Estimates at Schematic Design Phase

\begin{tabular}{|l|lr|rr|}
\hline \begin{tabular}{|l|lrl|l|}
\hline Description & \multicolumn{2}{l|}{ Davis Langdon } & & \multicolumn{1}{c|}{ Gilbane } \\
\hline \hline Opaque Wall Construction & $\$$ & $3,761,913$ & $\$$ & $5,149,532$ \\
Exterior Glazing Systems & $\$$ & $2,165,810$ & $\$$ & $3,459,230$ \\
Exterior Doors & $\$$ & 122,050 & $\$$ & 152,500 \\
Miscellaneous & $\$$ & 630,289 & $\$$ & - \\
\hline Total & $\mathbf{\$}$ & $\mathbf{6 , 6 8 0 , 0 6 2}$ & $\mathbf{\$}$ & $\mathbf{8 , 7 6 1 , 2 6 2}$ \\
\hline
\end{tabular}
\end{tabular}

\section{Variance between:}

$\mathrm{DL} \& O C$

DL \& CSU $2-7$

OC \& CSU $2-7$

$-9 \%$

Average DL \& OC to CSU 2-7

$5 \%$

\section{CSU 2-7 final project budget amount: $\quad \$ \quad 7,970,902$.}

\begin{tabular}{|c|c|c|c|c|c|c|}
\hline \multirow[b]{2}{*}{ Description } & \multicolumn{3}{|c|}{ Davis Langdon } & \multirow{2}{*}{\multicolumn{2}{|c|}{\begin{tabular}{|cc} 
& $\begin{array}{c}\text { Gilbane } \\
\text { Cost }\end{array}$ \\
Quantity & Unit $\quad$ Unit \\
\end{tabular}}} & \multirow[b]{2}{*}{ Total } \\
\hline & Quantity Uni & $\begin{array}{l}\text { Cost } \\
\text { /Unit }\end{array}$ & Total & & & \\
\hline \multicolumn{7}{|l|}{ Opaque Wall Construction } \\
\hline 8" CMU Penthouse Walls & & & & $3,140 \mathrm{SF}$ & 22.45 & 70,493 \\
\hline 4" Furring to basement walls & $3,310 \mathrm{SF}$ & 3.50 & 11,585 & & & \\
\hline Steel Lintels (angles) & $49,048 \mathrm{SF}$ & 1.50 & 73,572 & 25 Ton & $2,759.14$ & 68,979 \\
\hline 8"light gauge framing & $63,113 \mathrm{SF}$ & 8.50 & 536,461 & & & \\
\hline Rigid insulation & $63,113 \mathrm{SF}$ & 2.50 & 157,783 & & & \\
\hline Waterproofing & $63,113 \mathrm{SF}$ & 4.00 & 252,452 & & & \\
\hline Exterior sheathing, dens-glass & $63,113 \mathrm{SF}$ & 2.75 & 173,561 & & & \\
\hline Metal Panel System (Zinc Panels) & $24,974 \mathrm{SF}$ & 27.50 & $\$ 686,785$ & & & \\
\hline Zinc Panels on 8" stud back-up & & & & $13,344 \mathrm{SF}$ & 60.00 & $\$ 800,640$ \\
\hline Zinc Panels - Return to Remove Protective Shielding & & & & $13,344 \mathrm{SF}$ & 10.00 & $\$ 133,440$ \\
\hline Zinc Panels on Structural Steel Framing (incl Steel) & & & & $11,425 \mathrm{SF}$ & 90.00 & $\$ 1,028,250$ \\
\hline Brick Veneer & $49,048 \mathrm{SF}$ & 32.50 & $\$ 1,594,060$ & $48,841 \mathrm{SF}$ & 50.00 & $\$ 2,442,050$ \\
\hline Gypsum board to exterior walls-taped, sanded \& painted & $66,423 \mathrm{SF}$ & 4.15 & $\$ 275,655$ & & & \\
\hline Exterior Wall Back-up - Drywall Furring on 3-5/8" Studs & & & & $62,185 \mathrm{SF}$ & 8.00 & 497,480 \\
\hline Exterior Soffits & & & & $4,200 \mathrm{SF}$ & 21.00 & 88,200 \\
\hline Sub - Louvers \& Grilles & & & & $1 \mathrm{LS}$ & $20,000.00$ & 20,000 \\
\hline \multicolumn{7}{|l|}{ Exterior Glazing Systems } \\
\hline Interior window Sills & & & & $5,000 \mathrm{LF}$ & 20.00 & $\$ 100,000$ \\
\hline Exterior Wall Mock Up & & & & 1 ALW & $25,000.00$ & 25,000 \\
\hline Curtain Wall System - Concealed Header/Jamb & $5,731 \mathrm{SF}$ & 100.00 & $\$ 573,100$ & $12,563 \mathrm{SF}$ & 70.00 & $\$ 879,410$ \\
\hline Curtain Wall System - 2" Deep Horiz Snap Caps & $18,721 \mathrm{SF}$ & 70.00 & $\$ 1,310,470$ & $22,765 \mathrm{SF}$ & 100.00 & $\$ 2,276,500$ \\
\hline Structurally Glazed Double-height Curtainwall & $2,352 \mathrm{SF}$ & 120.00 & $\$ 282,240$ & $1,486 \mathrm{SF}$ & 120.00 & $\$ 178,320$ \\
\hline \multicolumn{7}{|l|}{ Exterior Doors } \\
\hline Doors/Frames/hardware, Exterior HM & & & & 8 LEAF & $1,500.00$ & 12,000 \\
\hline-- Single leaf & $5 \mathrm{EA}$ & $1,700.00$ & 8,500 & & & \\
\hline --Double leaf & $7 \mathrm{EA}$ & $3,250.00$ & 22,750 & & & \\
\hline Overhead Doors Elec Operated & & & & 1 EA & $2,500.00$ & 2,500 \\
\hline Entrance Doors - Glass/Alum & & & & 15 LEAF & $4,000.00$ & 60,000 \\
\hline --Single leaf & $1 \mathrm{EA}$ & $3,300.00$ & 3,300 & & & \\
\hline-- Double leaf & $10 \mathrm{EA}$ & $6,150.00$ & 61,500 & & & \\
\hline Entrance Door Auto Assist HW - Fire Glass/Alum, 2 hr FR & $4 \mathrm{EA}$ & & 26000 & 12 LEAF & $6,500.00$ & 78,000 \\
\hline \multicolumn{7}{|l|}{ Miscellaneous } \\
\hline Soffits - Metal Panel & $2,102 \mathrm{SF}$ & 47.50 & 99,845 & & & \\
\hline Soffits - Cement Planter & 892 SF & 30.00 & 26,760 & & & \\
\hline Roof screen including structural support, metal panel (12') & $6,744 \mathrm{SF}$ & 50.00 & 337,200 & & & \\
\hline Galvanized guardrail at terraces, 4 feet high & $240 \mathrm{LF}$ & 220.00 & 52,800 & & & \\
\hline Fascias, bands, screens \& trim & $113,684 \mathrm{SF}$ & 0.50 & 56,842 & & & \\
\hline Architectural detailing & $113,684 \mathrm{SF}$ & 0.5 & 56842 & & & \\
\hline Total & & & $\$ 6,680,062$ & & & $\$ 8,761,262$ \\
\hline
\end{tabular}




\section{Design Development Phase*}

Again in the Design Development Phase, independent cost estimates were prepared by Davis Langdon, and by Gilbane. In organizing Table 9, the descriptions and quantities were compared. The cost estimates are becoming more detailed as the building systems are defined.

Both ZGF and Gilbane were attempting to maintain the design intent, while holding to the construction budget. The variance between the two estimates is 26 percent. Both Davis Langdon and Gilbane are above the final CSU allocation of $\$ 7,970,902$ (9 percent and 27 percent, respectively). The average of their differences is 18 percent above the CSU allocation.

Optional materials and details for the exterior were explored in an attempt to bring the final building in-line with the budget. It was becoming increasingly clear that the budget approved by the CSU was inadequate, even after exploring and applying several value engineering options, including a less durable exterior material. The cost of other building systems would have to be reduced to makeup for the shortfall in the exterior enclosure costs, and to bring the overall project costs in-line with the budget.

"Confirms or adjusts all aspects of the schematic plans (exterior design, mechanical and electrical systems, telecommunications system, structural systems, area arrangements, foundation plans, etc.). Documents include plans, outline specifications and cost estimates developed in further detail than schematic documents. 
Table 9. Cost Estimates at Design Development Phase

\begin{tabular}{|c|c|c|c|c|}
\hline \multicolumn{5}{|c|}{ Summary } \\
\hline Description & & s Langdon & & Gilbane \\
\hline Opaque Wall Construction & $\$$ & $\overline{5,536,972}$ & $\$$ & $6,882,309$ \\
\hline Exterior Glazing Systems & $\$$ & $2,095,190$ & $\$$ & $3,823,925$ \\
\hline Exterior Doors & $\$$ & 153,800 & $\$$ & 190,540 \\
\hline Miscellaneous & $\$$ & 960,599 & $\$$ & 95,780 \\
\hline Total & $\$$ & $8,746,561$ & $\$$ & $10,992,554$ \\
\hline
\end{tabular}

Variance between:

$D L \& O C$

$26 \%$

DL \& CSU 2-7

OC \& CSU $2-7$

$-9 \%$

Average DL \& OC to CSU 2-7

$-27 \%$

$-18 \%$

CSU 2-7 final project budget amount: $\quad \$ \quad \mathbf{7 , 9 7 0 , 9 0 2}$ 


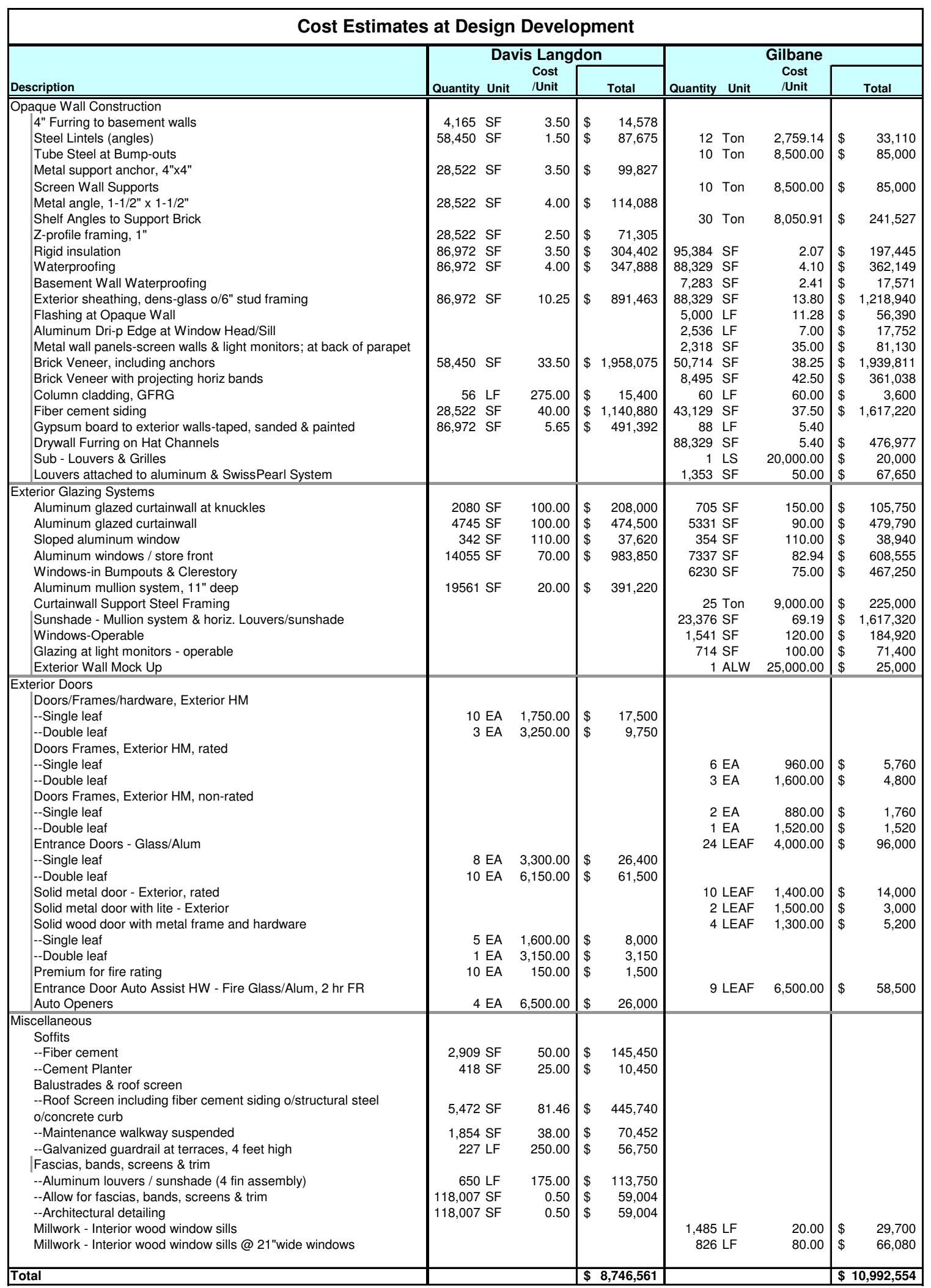




\section{Construction Documents Phase*}

During the 50\% Construction Documents Phase, Davis Langdon and Gilbane had highly detailed information in the Construction Documents from which to prepare their independent cost estimates. At this point in the project, the exterior skin plans included elevations, sections, details and specifications (Figure 9).

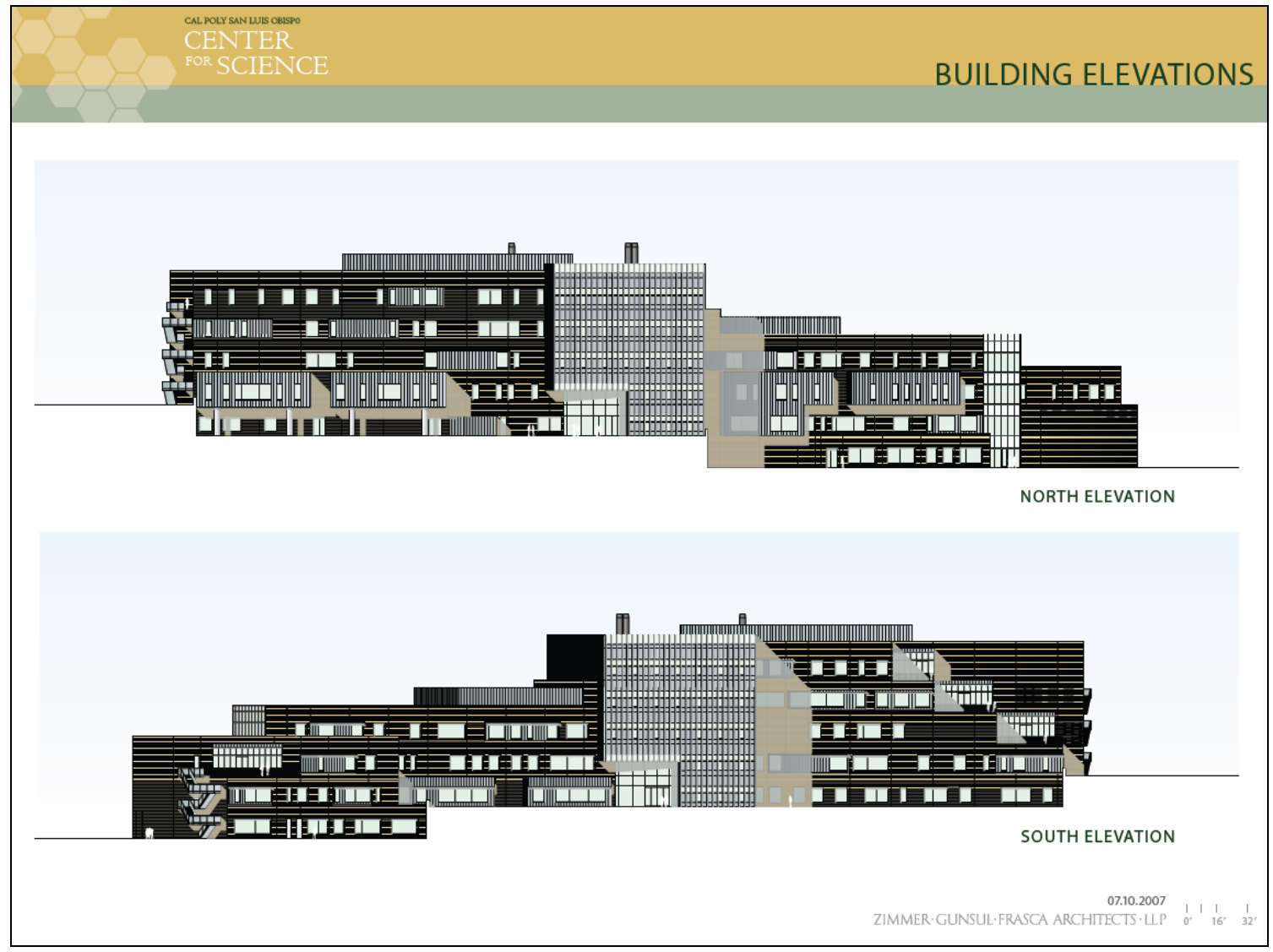

Figure 9. Center for Science - Building Elevations. Source: California Polytechnic State University, San Luis Obispo, Facilities Planning and Capital Project, Center for Science Project, drawings by ZGF (10 July 2007).

"Sets forth, in detail, all aspects of project design, function, and construction. Documents area used for estimating the cost of the project, securing bids for its construction, and directing the contractor during the construction period. Documents include detailed construction drawings, and material and building system specifications. 
In organizing Table 10, the descriptions were compared and correlated. At this phase in the project, ZGF and Gilbane continued to maintain the design intent, while holding to the construction budget.

Both Davis Langdon and Gilbane are above the final CSU allocation of $\$ 7,970,902$ (23 percent and 26 percent, respectively). The average of their differences is 25 percent above the CSU allocation, while they differ from each other by only 3 percent.

Refinement of optional materials and the details for the exterior and cost reduction of other building elements were needed to bring the final building in-line with the budget. The analysis of the cost estimates show that the initial assumptions and the final CSU allocation for the exterior skin of the building were too low.

Table 10. Cost Estimates at Construction Documents Phase

\begin{tabular}{|l|lr|rr|} 
Summary \\
\begin{tabular}{|l|lr|r|r|}
\hline Description & \multicolumn{2}{|l|}{ Davis Langdon } & \multicolumn{1}{c|}{ Gilbane } \\
\hline \hline Opaque Wall Construction & $\$$ & $5,077,312$ & $\$$ & $6,019,055$ \\
Exterior Glazing Systems & $\$$ & $3,863,115$ & $\$$ & $4,485,375$ \\
Exterior Doors & $\$$ & 350,600 & $\$$ & 173,230 \\
Miscellaneous & $\$$ & $1,108,602$ & $\$$ & 78,440 \\
\hline Total & $\$$ & $\mathbf{1 0 , 3 9 9 , 6 2 9}$ & $\mathbf{\$ 1 0 , 7 5 6 , 1 0 0}$ \\
\hline
\end{tabular}
\end{tabular}

Variance between:

DL \& OC

DL \& CSU $2-7$

OC \& CSU $2-7$

$-23 \%$

Average DL \& OC to CSU 2-7

$-26 \%$

$-25 \%$

CSU 2-7 final project budget amount: $\quad \$ 7,970,902$ 


\section{Cost Changes Over Time by Building System}

From the time the Construction Manager first looked at the project to the 50 percent Construction Documents (a twelve-month period), the Project Team increased costs for two systems, and decreased costs for two systems, plus decreased overhead and profit (OH\&P), General Condition expenses and Project Contingency (Figure 10). The exterior enclosure costs doubled from $\$ 6$ million to $\$ 12$ million. Costs for two other building systems remained relatively constant.

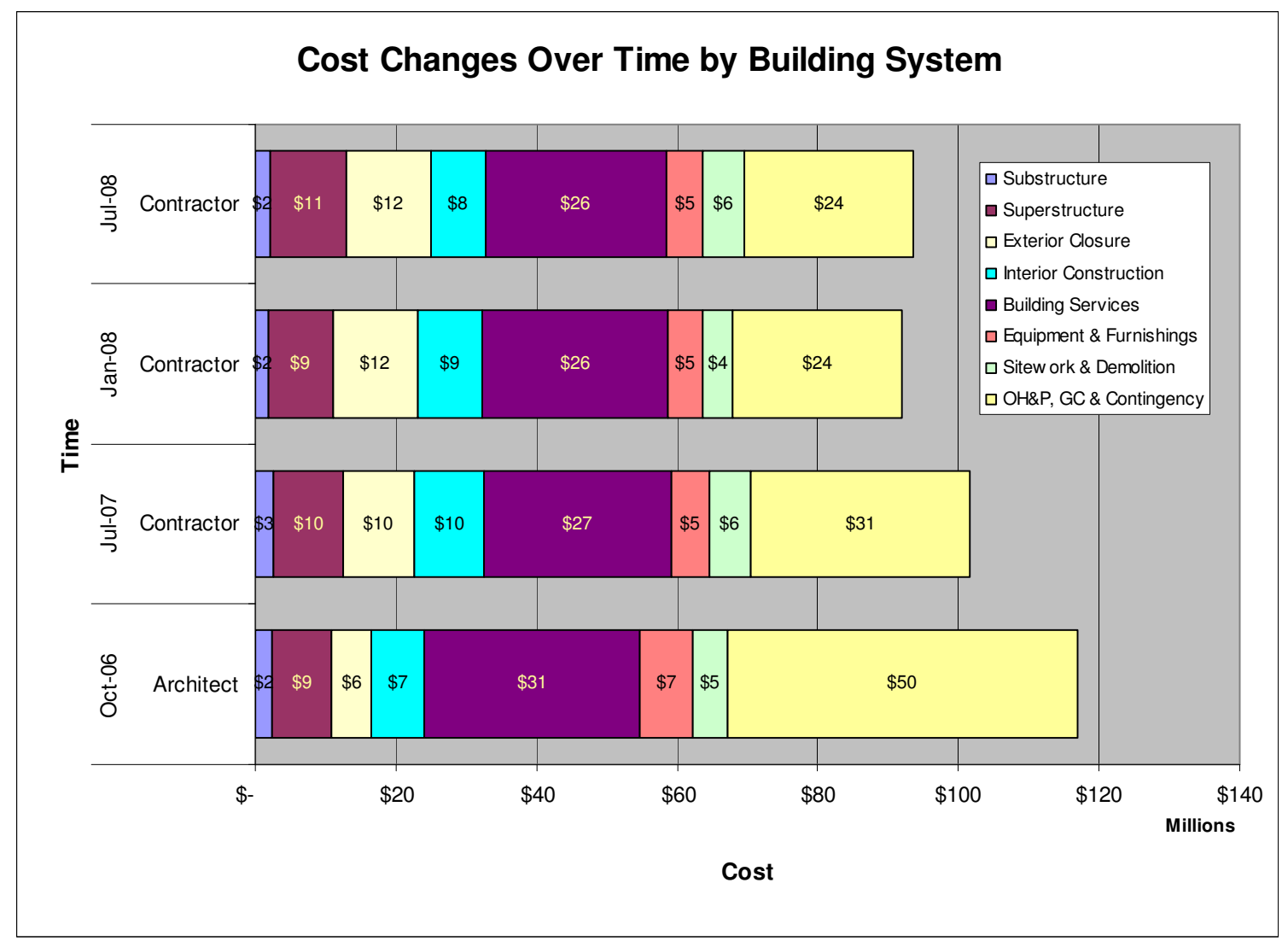

Figure 10. Cost Changes Over Time by Building Systems. Sources: Data adapted from RRM "Program," and Gilbane "Schematic," "Design Development," and "Schematic."

With the total costs above budget, two building systems were explored further in the hopes of decreasing costs. Ultimately, the project was brought in-line with the budget by reducing costs in building services (specifically mechanical), and equipment and furnishings. The costs were reduced to 2 percent below the CSU 
allocation, and the project continued to completion of the 100 percent Construction Documents (Table 11).

Table 11. Difference between Budget and Construction Costs

\begin{tabular}{lrc}
\hline Budget & \multicolumn{1}{c}{ Costs } & Percentage \\
\hline CSU 2-7 final & $\$ 95,723,000$ & $100 \%$ \\
Gilbane & $\$ 93,520,626$ & $98 \%$ \\
\hline Difference & $\$ 2,202,374$ & $2 \%$ \\
\hline
\end{tabular}

The costs for many of the building systems over the twelve-month period differ greatly from the budget established during the programming phase and from the final CSU budget (Figure 10). For the exterior skin, and specifically the curtain wall system, the architect and constructor were each envisioning a different system. The program architect originally envisioned a standard curtainwall system, while the design architect envisioned creating a unique curtainwall system and did not realize the cost implications. In the end, the architect and constructor worked together to arrive at a solution that preserve the design intent, improved on other building systems and maintained the CSU project budget. The design and material assumptions were the areas of consistent tension in the costs estimates. While both estimators were reviewing the same information, each made different assumptions about materials, systems and quantities. Although their cost estimates differed consistently by system during the Schematic and Design Development phases, and their final cost estimates for the Construction Documents phase differs slightly for some building systems, both agreed on the overall project costs for the construction budget at the 50 percent point in the Construction Documents phase (Figure 11). 


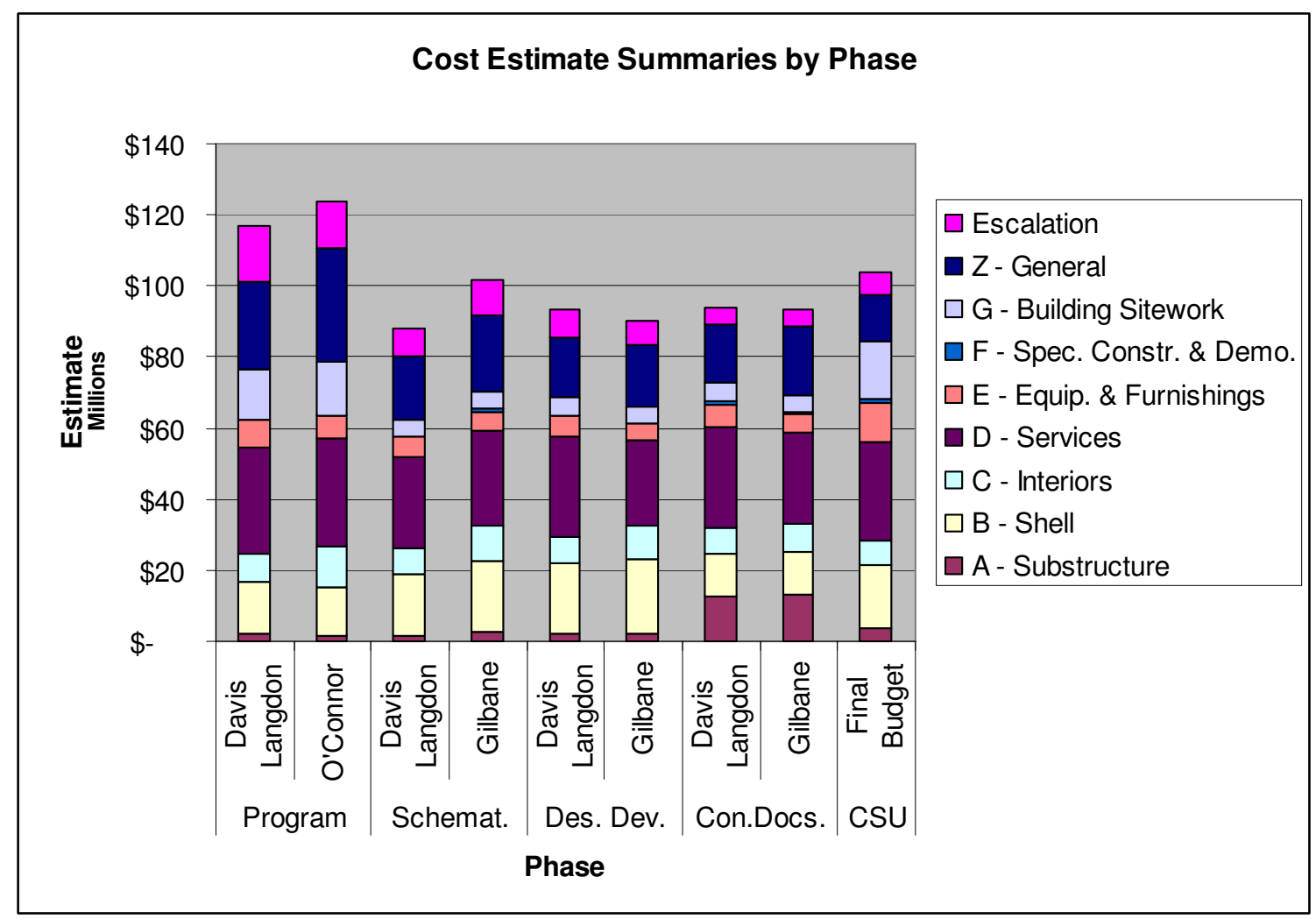

Figure 11. Cost Changes Over Time by Phase. Sources: Data adapted from RRM "Program," and Gilbane "Schematic," "Design Development," and "Schematic."

Ideally, the options, assumptions, and decisions for the Center for Science would have been known to all Project Team members at each phase of the project. Because the project information was developed and shared in a 2-D format, visualization of the project and all its components was open to a wide range of assumptions and interpretations by each team member.

Interoperability, the process, and Building Information Modeling, the tool, present new ways of developing, documenting and viewing project information. As observed by Brent Pilgrim, if used as intended, BIM would allow architects to make earlier and more definite assumptions, and to share those assumptions with the rest of the team. He notes that this can be uncomfortable for architects, because each assumption is documented and a cost applied. However, Pilgrim also states that "one can expect the assumptions to change later, but everyone 
knows the assumptions, and the cost estimate is in-line with those assumptions." 15

BIM would allow options to be carried in the project data until a clear choice is determined. Having information about the options in the model as the project progresses would allow the Project Team members to add and analyze information leading to a decision. If the BIM were viewed as a puzzle, then Team members would be able to watch and participate in solving the puzzle by adding pieces where needed, discarding pieces that don't fit, and working together to make sure no pieces were missing.

Dane Dodd-Hansen, an architect and specification consultant, who chairs CSI's BIM Technology Committee states that BIM enables "moving the decisionmaking process and information gathering process to the front end of the project." ${ }^{\text {16 }}$ He continues that it is important to share information with all team members from initiation of the project. "Basically, the thing that they are doing right from the beginning is to bring everybody that's involved in the process into the same room, right from the get go on every project."17

\section{Case Study Conclusions}

Realizing the need to work differently by involving more team members earlier in the design process, the AIA has gone from recommending a Traditional Design process (Figure 4) to an "Integrated Project" process as is illustrated in Figure 12. In the Integrated Project process, Design Consultants (civil, structural, mechanical, electrical, plumbing, controls, special, etc.) and Constructors are brought in earlier during what was previously known as the Predesign Phase in the traditional design process.

In the Integrated Project process, Design Consultants (civil, structural, mechanical, electrical, plumbing, controls, special, etc.) and Constructors are brought in earlier during what was previously known as the Predesign Phase in the traditional design process. "Shifting design decision making forward," with "early input from constructors, installers, fabricators and suppliers," and with "the ability to model and simulate the project accurately using BIM tools" enables "the 
design to be brought to a much higher level of completion before the documentation phase is started." 18

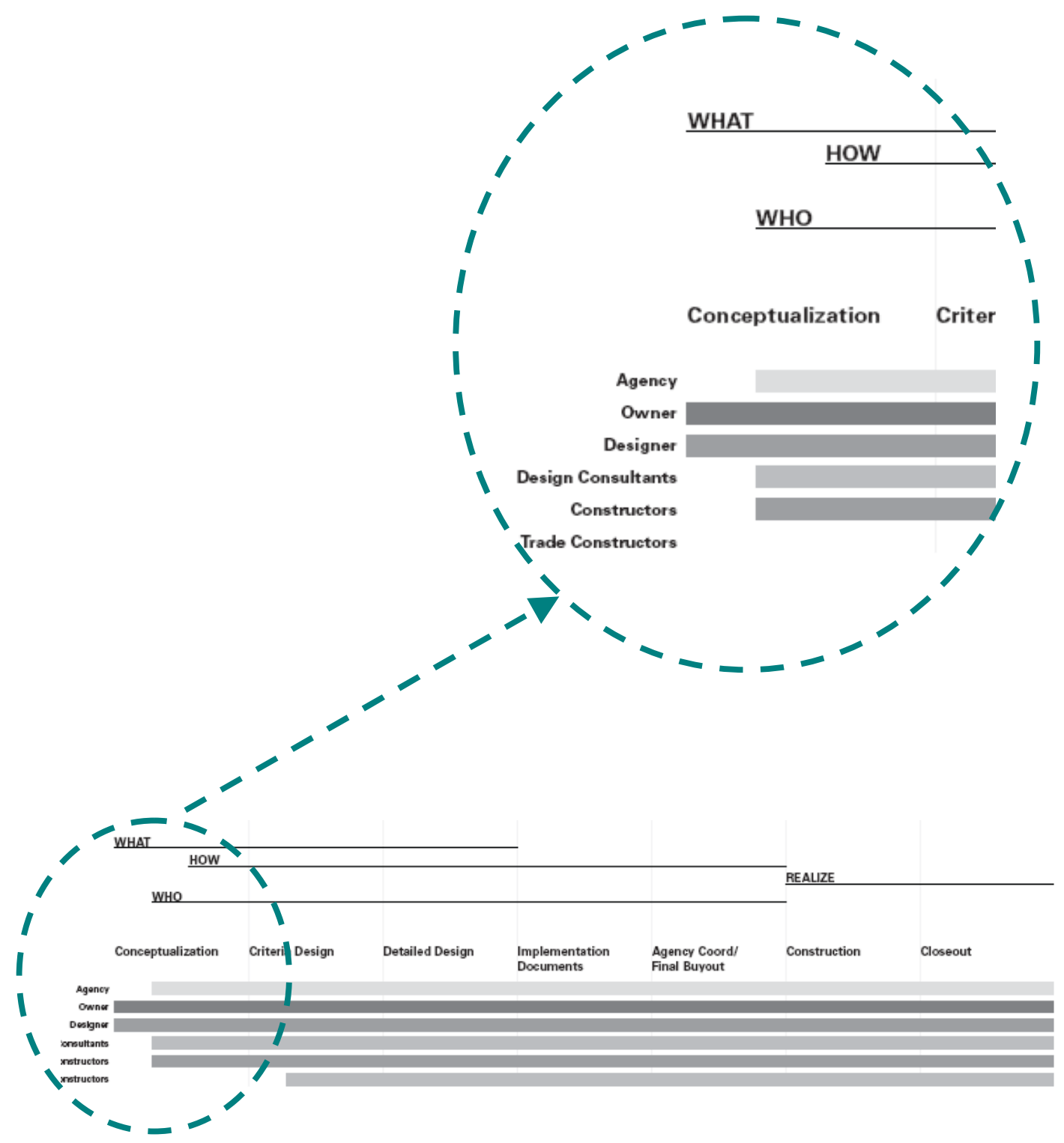

Figure 12. Integrated Design Process Model. Source: Data from AIA National/AIA California Council, Integrated Project Delivery: A Guide, version 1 (The American Institute of Architects, 2007), table page 22.

Derived from Brent Pilgrim's examination of the cost estimates prepared at each project phase by two separate estimators, he speculates that without clear definition of the project assumptions, each estimate was based on individual interpretation of the design intent. This is reflected in part by the variations in materials, systems and quantities in the estimates. In his opinion, the Center for 
Science project would have benefitted greatly if the entire team had been brought together to visualize and communicate the project, including assumptions and options, clearly defining the project using a 3-D tool and building information modeling. ${ }^{19}$

In the viewpoint of Chris Pechacek, BIM would have benefited the Center for Science project by illuminating the gaps in project definition required to develop the cost estimate. He further adds that using BIM would have eliminated disconnects in obtaining accurate costing information by enabling the project team to be tied into the design process to fill in the gaps and contribute to the project solution, noting that "every time we rehandle information, we introduce error." ${ }^{20}$ Pechacek is also a proponent of using information for different purposes to create more value and save time. He observed that had the Center for Science project been created in a BIM, the information could have been used to create the renderings, drawings and cost estimates, and further down the road, the shop drawings.

Based on the appraisal of the Center for Science project as the construction manager, Mark Miller of Gilbane Building Company believes that the project would have benefited if the complex project elements had been developed using BIM. Miller stated that the real benefit of BIM is "seeing how all the elements come together," ${ }^{21}$ and that would have been helpful, especially on the east section of the $4^{\text {th }}$ floor. He noted that the numerous building elements and seismic bracing were causing conflicts that the architect had not visualized during design and was having difficulty understanding the challenges seismic bracing was causing in an area congested with mechanical ducts and equipment.

In considering the potential benefits to the Center for Science project, Cal Poly project administrator, Johan Uyttewaal is of the belief that the advantages of BIM are greatest for the construction manager, especially in the crash detection and as a tool for the construction process. ${ }^{22}$

Based on the opinion of Cal Poly project manager, Barbara Queen, had an integrated process using BIM software been utilized on the Center for Science 
project from the start, time would have been saved by the campus, architects, consultants and construction manager since all would have had access to complete project information and been able to utilize it at every step in the work. ${ }^{23}$ Also, the knowledge and input of these team members would have helped to reduce waste and maximize efficiency from programming through design.

Thorton Tomasetti, an international engineering company, notes on their website that BIM promises to provide "enhanced visualization, linked data sets, improved design team coordination, expedited quantity takeoffs, better scope definition and improved schedule," and that IPD will enhance the project delivery as it leverages "the many advantages inherent in BIM."24

With the knowledge gained from examining the Center for Science case study and the professional opinions and consensus of the project team members, plus the insight gained from experts in the construction industry, an approach and recommendations were developed for the university to initiate incorporating the advantages of IPD and BIM into its projects. These recommendations, enumerated in Chapter 3 , are intended as the first steps.

\footnotetext{
${ }^{1}$ The Construction Specifications Institute, The Project Resource Manual-CSI Manual of Practice, $5^{\text {th }}$ ed. (New York: McGraw-Hill, 2005), 1.1.

${ }^{2} \mathrm{CSI}$ PRM, 3.23.

${ }^{3}$ Cyril M. Harris, Dictionary of Architecture and Construction, $4^{\text {th }}$ ed. (New York: McGraw-Hill, 2006), 767-768.

${ }^{4}$ William Peña, Steven Parshall, and Kevin Kelley, Problem Seeking: An Architectural Programming Primer (Washington: AIA Press, 1987), 15.

${ }^{5}$ Peña, Parshall, and Kelley, 181-182.

${ }^{6}$ The California State University, "SUAM, Section I - Capital Outlay and Public Works Contracts, Sections 9000-9004" (Rev 11.02), http://www.calstate.edu/CPDC/SUAM/SUAM90009004.pdf (accessed 13 May 2008), Section 9001.

${ }^{7}$ The California State University, "SUAM, Section I - Capital Outlay and Public Works Contracts, Sections 9025-9040," (Rev 12.02), http://www.calstate.edu/CPDC/SUAM/SUAM90259040.pdf (accessed 13 May 2008), Section 9028.

${ }^{8}$ The California State University, "SUAM, Appendix B: Facilities Planning," http://www.calstate.edu/cpdc/suam/Appendices/Appendix B.shtml (accessed 20 May 2008).
} 
${ }^{9}$ The California State University, "SUAM, Appendix B: Facilities Planning," http://www.calstate.edu/cpdc/suam/Appendices/Appendix B.shtml (accessed 20 May 2008), CSU CPDC Form.

${ }^{10}$ Capital Outlay Budget Change Proposal: $2007 / 08$ State and Non-State Capital Outlay Program (November 2006); RRM Design Group, The Center for Science: Program Document and Feasibility Study, California Polytechnic State University, San Luis Obispo (October 2006), 8.

${ }^{11}$ RRM, 8.

${ }^{12}$ California Polytechnic State University, "Request for Proposal - Construction Manager at Risk with Guaranteed Maximum Price - Center for Science RFP MAJ 06-310, Article B Information for Proposers," (15 January 2007), 6.

${ }^{13} \mathrm{RRM}, 57$.

${ }^{14} \mathrm{RRM}, 57$.

${ }^{15}$ Brent Pilgrim, telephone interview by author, (26 November 2008).

${ }^{16}$ Dane Dodd-Hansen, telephone interview by author, (21 November 2008).

${ }^{17}$ Dodd-Hansen.

${ }^{18}$ AIA National / AIA California Council, Integrated Project Delivery: A Guide, version 1 (The American Institute of Architects, 2007,: 22.

${ }^{19}$ Pilgrim.

${ }^{20}$ Christopher Pechacek, telephone interview by author, (26 November 2008).

${ }^{21}$ Mark Miller, telephone interview by author, (09 January 2009).

${ }^{22}$ Barbara Queen and Johan Uyttewaal, interview by author, San Luis Obispo, CA, (09 January 2009).

${ }^{23}$ Queen and Uyttewaal.

${ }^{24}$ Thorton Tomasetti, Website, http://www.thorntontomasetti.com/project_delivery.php (accessed 6 January 2009). 


\section{CHAPTER 3}

\section{Justification, Assumptions and Recommendations}

\section{Justification of Issues}

\section{Industry Changes Necessitate Process Changes}

As the construction industry moves toward BIM, propelled by new software tools, integrated project delivery is becoming the process that will allow the project team to work in a better, more efficient manner through all phases of a project. As tools for each participant are developed and information becomes integrated into a complete and accessible building information model, the industry must respond by changing to an integrated design process to benefit fully from the interoperability of the systems. Until this occurs, project information will be fragmented and lost, and the construction industry will continue to be inefficient and frustrated by the ever increasing building complexity. The benefits are many and available to those who participate using BIM and an integrated process.

The individual experts interviewed for this thesis each have a different approach to projects. Each demonstrates in a different way how they are modeling their business to embrace BIM and improve upon the work processes and the project outcomes. Beck Technology has responded to the industry changes by providing integrated project services similar to design-build. However, they are unique in that design and construction are all part of the same company and all share the same bottom line. ${ }^{1}$

Dodd-Hansen Consulting has expanded their specification writing services (to assist firms moving into new initial delivery processes) by gathering information on materials and systems at the beginning of a project to provide the means for earlier decision making. Dane Dodd-Hansen describes the Basis of Design in the conceptual phase as "essentially a response to the owner's requirements for the project" where the probable products and systems are defined, and "put together in a component specification." 
earlier to all team members so that all are working from the same assumptions. Dodd-Hansen notes the advantage, "It moves everybody onto that early page very, very effectively."3

Onuma, Inc. is focusing on early planning and facility management. Their webbased software tools allow owners to do early programming and feasibility analysis. When initiating a project, the requirements can be cataloged or assembled and shared with the project team. Instead of a static document, information can continue to be added throughout the life cycle of the building. Additionally, owners with large and multiple facilities benefit greatly by being able to manage their space allocation and requirements. For large and multiple facility owners, such as the United States General Services Administration (GSA) and the United States Coast Guard, these types of tools enable them to manage existing facilities and plan for future facilities. ${ }^{4}$

In 2003, GSA began a pilot program to leverage 3-D-based BIM to improve "cost predictability." GSA hoped to "ensure better as-built documentation, communication, design delivery, and coordination." As a result of the successes with the pilot program, the Commissioner of the Public Buildings Services mandated the use of interoperable BIM for cost-effective delivery of GSA projects."7

\section{Transformation of Information Sharing}

The holistic nature of BIM provides significant opportunities for all members of the building team. For example, team members with access to the project information can be aware of all changes being made in real time-a substantial information sharing and coordinating opportunity. BIM can allow information created in the programming and conceptual design phase to be carried throughout subsequent phases with information being added or modified as the project progresses. BIM can reduce errors made by the design and construction team members by checking for conflicts in the drawings, such as a pipe penetrating a duct and a duct cutting through a critical structural member. It can free-up time spent on door and window schedules by creating dynamic 
schedules that update automatically as changes are made. It can be used to provide analysis such as daylighting and energy usage simulations, and to aid the design, cost estimating, and decision making for building systems.

GSA realized direct benefits to their pilot projects. These included a 19 percent reduction in the construction schedule duration, improvement in as-built documentation, early discovery of design errors and omissions, and improvement in the means of communication with tenant agencies and during pre-bidding conferences. $^{8}$ As team members obtain access to all changes being made in real time, the transformation of information sharing will be realized, and information created in programming will be carried throughout subsequent phases.

Working in a Collaborative Environment

As the industry embraces the use of BIM, and team members have access to information and changes in real time, project teams will need to collaborate to work in the best interests of the project. The Integrated Project Delivery requires close cooperation among team members, and aligns "participant success to project success." The focus by team members will shift form individual expectations to "collectively achieving shared goals."10

\section{Assumptions and Recommendations}

\section{Approach}

Chris Pechacek of Parsons Corporation, an engineering and construction firm recommends starting at the end and working towards the beginning of a project (as is done by constructors with Reverse Phase Scheduling) to identify what is needed, from whom it is needed and when it is needed. ${ }^{11}$ Rather than going to the end of a building's life at the de-commissioning phase, the assumptions in this thesis are based on working backwards from the Schematic Design and Design Development Phases, and determining what information should be passed onto the Design Architect from the Program Architect. Although the approach used in this thesis was developed using Reverse Phase Scheduling 
concepts beginning at the design phase, the assumptions are introduced in project sequence beginning with the information the University may provide to the Program Architect at the project initiation.

Project Initiation - Need and Vision Statement

For universities within the CSU system, project need is based on the projected number of additional full-time equivalent (FTE) students and the resulting requirement for the additional square footage (Table 2). To begin defining the project scope, a vision for the project is developed by the Dean working in concert with the Provost, or the Department Head working in concert with the Vice-President, and is presented as a Vision Statement. Both the Dean and the Department Head typically involve a committee to collaborate and develop the vision as the project idea originates. With the vision statement ready, the University hires a Program Architect to develop the programming and feasibility study. The criteria given to the potential Program Architects includes the Vision Statement, the FTE number, the approximate size and the anticipated CSU construction budget. Additional information is provided once a Program Architect is selected and programming begins.

\section{University to Program Architect}

At initiation of the programming and feasibility study, the University provides site, topographical and utility maps, surveys, existing building plans and specifications, and campus and CSU standards to the Program Architect. This information is available in various forms, including on-line as pdf and AutoCAD files, and in electronic and hard copy for programming, planning, building consideration and analysis and is used by the Program Architect to define site and building options and constraints. (Table 12) 


\section{Table 12. List of Information Provided by Cal Poly to Program Architect}

\begin{tabular}{|c|c|c|c|c|c|c|}
\hline Information & $\begin{array}{l}\text { On- } \\
\text { line }\end{array}$ & PDF & AutoCAD & Word & Excel & $\begin{array}{l}\text { Hard } \\
\text { Copy }\end{array}$ \\
\hline Campus Master Plan & - & $\bullet$ & $\bullet$ & & & \\
\hline Existing Buildings Plans \& Specs & • & $\bullet$ & - & & & • \\
\hline Site Utility Maps & • & - & - & & & \\
\hline Room Data Sheets Layout & & $\bullet$ & & & & \\
\hline Existing Buildings Area & & & & & $\bullet$ & \\
\hline Existing Buildings Usage & & & & & $\bullet$ & \\
\hline $\begin{array}{l}\text { CSU Program Summary Spreadsheet } \\
\text { Format }\end{array}$ & & & & & $\bullet$ & \\
\hline Campus Standards & & $\bullet$ & & - & & \\
\hline FTEs to accommodate & & & & $\bullet$ & - & \\
\hline CSU Building Design Standards & - & - & & & & \\
\hline
\end{tabular}

Source: Data from interview with Rex Wolf, Facility Services, California Polytechnic State University, 9 December 2008.

Considering the information that will be developed and the formats most likely to be utilized, three recommendations are provided to the University. When information can be developed in an alternate format more compatible to a BIM, an alternate is given.

Recommendation \#1 - Improve upon the information received from others and provided to the Program Architect.

It would be beneficial for information to be in an open standard, such as IFC format, so that it can be accessed by the Project Team. In the interim, continue to provide the information in its original software file configuration. For example, if the Campus Utility Plan maps are available in AutoCAD, continue to allow the Program Architect access to the files for utilization of the information without 
having to recreate it. This same desire would apply to other maps and building information.

Better yet, if the information could be provided in a parametric, 3-dimension format, such as GIS* or Revit, ${ }^{\dagger}$ then the underground depth and relationship to other utilities could be established resulting in more accurate analysis, scope and cost estimate. According to Rex Wolf in Facility Services at Cal Poly, the University currently has no plans to research and document underground utility data into a 3-D model, but would accept the information as it is developed and submitted for campus projects. The University should require their consultants to provide project information in a parametric 3-D format on future projects.

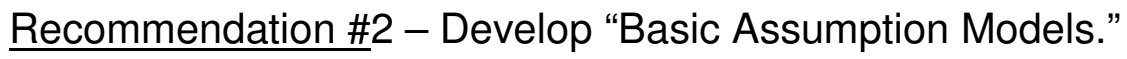

Many of the building spaces required by the University are standardized for size, material, equipment and furniture. It would be beneficial to Program Architects to be able to receive space-type information in the form of "Basic Assumption Models"12 rather than requiring each firm to create these. Presently at conclusion of programming, this information is provided to the University in a non editable format and cannot be changed except by the originating firm (Figure 13).

"Geographic Information System that integrates hardware, software, and data of geographically referenced information. Refer to Glossary for further information.

${ }^{\dagger}$ Building design software for building information modeling. Refer to Glossary for further information. 


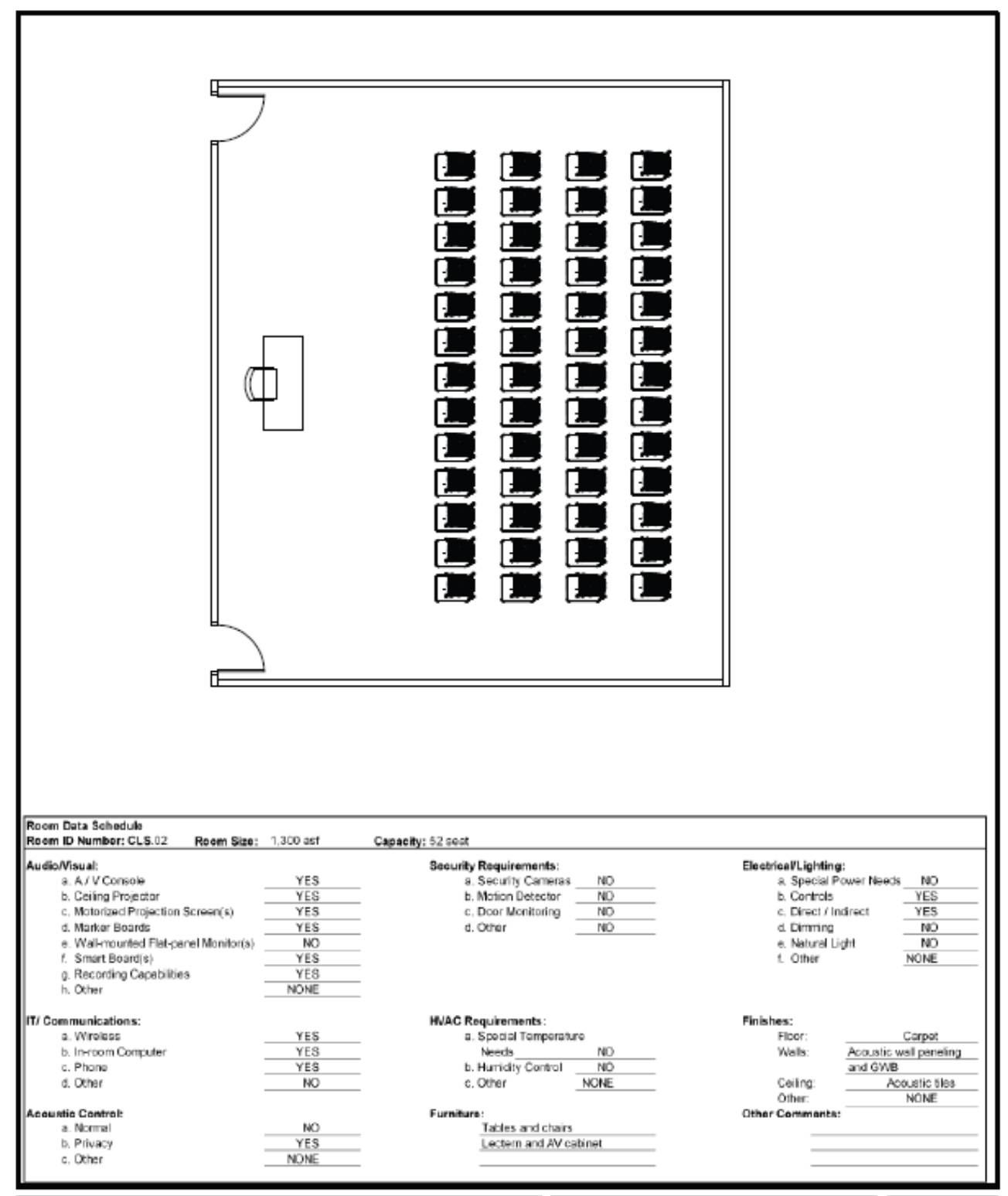

KILLEFER FLAMMANO ARCHITECTS

Ancmancturn

SHEPLEY BULFINCH RICHARDSON \& ABBOTT

namprose trotentoo Dastom

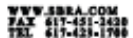

\begin{tabular}{|c|c|}
\hline $\begin{array}{r}52 \mathrm{SE} \text {. } \\
\text { saren mis } \\
\end{array}$ & $\begin{array}{l}\text { TIERED CLASSROOM } \\
\text { MIVBISITY cLAssioows }\end{array}$ \\
\hline nouser & $\begin{array}{c}\text { CAL POLY } \\
\text { wex tus obismo,ca }\end{array}$ \\
\hline
\end{tabular}

$\operatorname{sen}$ motit onsm. 2 smanan, am

Figure 13. Room Data Sheet. Source: Data from Killefer Flammang “Program.” Page 189. 
The University should require the Program Architect to provide Room Data Sheet information in a configuration that will become part of the data base to be reused and revised as the project progresses (Figure 14). If the Basic Assumption Models were incorporated into a campus project data base, then it would be available for use whenever the need arose. To initiate creation of this endeavor, Cal Poly should develop a format for 3-D and non-3-D parts of the room data sheets that would make utilization and sharing of the information easier. As Onuma suggests, the owner "instead of having a whole stack of Excel files or documents, and saying here's the project we are thinking of doing, actually hand them a BIM data file saying here's all the pieces that we are considering using."13 The benefit to the University would be that the Program Architect could spend more time on developing and analyzing options, and less time on producing standard, seldom changing information.

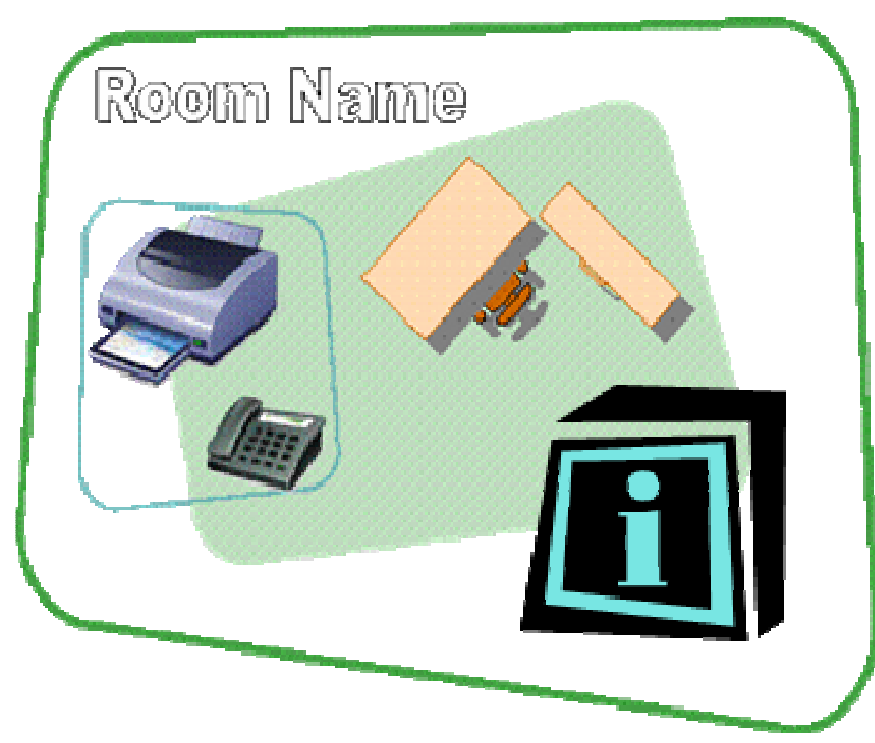

Figure 14. Basic Assumption Model - Data Base with Room Data Sheet Information. Source: Clip Art from Microsoft Office 2003.

Recommendation \#3 - Provide CSU CPDC Forms to the Program Architect, and develop innovative ways to extract and present the information using BIM.

Until the CSU Campus Planning, Design and Construction (CPDC) begins to implement BIM in capital planning, the forms required for inclusion in the Capital 
Outlay Program should be added to the list of information provided to the Program Architect (Table 13). This would guide the Program Architect in the type of information needed by the University, and make the information provided by the campus to the CSU easier to extract.

\section{Table 13. List of CSU CPDC Forms to Provide to Program Architect}

\begin{tabular}{|c|c|c|c|c|}
\hline CPDC Form Name & $\begin{array}{l}\text { Form } \\
\#\end{array}$ & Purpose & $\begin{array}{l}\text { Benefit } \\
\text { Program } \\
\text { Architect }\end{array}$ & $\begin{array}{l}\text { Benefit to } \\
\text { Cal Poly }\end{array}$ \\
\hline $\begin{array}{l}\text { COBCP Project } \\
\text { Description }\end{array}$ & $1-4$ & $\begin{array}{l}\text { Summary of proposal for } \\
\text { Capital Outlay Program, } \\
\text { including alternatives, } \\
\text { recommended solutions, } \\
\text { consistency with State AB } \\
857 \text { and AB } 32\end{array}$ & $\begin{array}{l}\text { Information to } \\
\text { analyze and } \\
\text { develop }\end{array}$ & $\begin{array}{l}\text { Information required of } \\
\text { University for submittal } \\
\text { to CSU for project } \\
\text { approval and funding } \\
\text { allocation }\end{array}$ \\
\hline $\begin{array}{l}\text { Summary of } \\
\text { Space } \\
\text { Requirements for } \\
\text { a Building }\end{array}$ & $2-4$ & $\begin{array}{l}\text { List of spaces proposed by } \\
\text { project, description, type, } \\
\text { size, stations, FTEs }\end{array}$ & $\begin{array}{l}\text { Use to develop } \\
\text { program }\end{array}$ & $\begin{array}{l}\text { Information required of } \\
\text { University for submittal }\end{array}$ \\
\hline $\begin{array}{l}\text { Room } \\
\text { Specifications }\end{array}$ & $2-6$ & $\begin{array}{l}\text { Room Data Sheets; program } \\
\text { on a room by room basis }\end{array}$ & $\begin{array}{l}\text { Format required } \\
\text { by University }\end{array}$ & $\begin{array}{l}\text { Information presented } \\
\text { in a reusable format }\end{array}$ \\
\hline $\begin{array}{l}\text { Summary of } \\
\text { Component Costs }\end{array}$ & $2-7.5$ & Summary of Project Costs & $\begin{array}{l}\text { Define UniFormat } \\
\text { level and } \\
\text { components for } \\
\text { cost estimate } \\
\text { summary }\end{array}$ & $\begin{array}{l}\text { Eliminate need for } \\
\text { translating information } \\
\text { into CSU format }\end{array}$ \\
\hline $\begin{array}{l}\text { Energy \& Utilities } \\
\text { Planning } \\
\text { Checklist }\end{array}$ & $2-8$ & $\begin{array}{l}\text { Questions and issues to } \\
\text { address prior to submitting } \\
\text { project to CSU }\end{array}$ & $\begin{array}{l}\text { Checklist of } \\
\text { information to } \\
\text { consider and } \\
\text { provide University }\end{array}$ & $\begin{array}{l}\text { Information required of } \\
\text { University for submittal }\end{array}$ \\
\hline $\begin{array}{l}\text { Information } \\
\text { Technology } \\
\text { Planning Sheet }\end{array}$ & $2-8.5$ & $\begin{array}{l}\text { Provides guidance crucial to } \\
\text { the design and } \\
\text { implementation of cable } \\
\text { system interface }\end{array}$ & $\begin{array}{l}\text { List of information } \\
\text { to consider, } \\
\text { develop and } \\
\text { provide University }\end{array}$ & $\begin{array}{l}\text { Information required of } \\
\text { University for submittal }\end{array}$ \\
\hline Equipment List & $2-23$ & $\begin{array}{l}\text { List and estimated cost of } \\
\text { Group II Equipment }\end{array}$ & $\begin{array}{l}\text { Information to be } \\
\text { included on Room } \\
\text { Data Sheets }\end{array}$ & $\begin{array}{l}\text { Development of } \\
\text { Group II equipment } \\
\text { lists }\end{array}$ \\
\hline
\end{tabular}

Source: The California State University, "Major Capital Outlay Forms,"
http://www.calstate.edu/cpdc/Facilities_Planning/majorcapoutlay.shtml (assessed 08 December 2008).

The next level up would be to put this information into the BIM, and extract it in a format compatible with the CSU Forms. Also, CSU may want to consider 
revising these forms and the manner in which the information is presented, shared, and utilized.

\section{Program Architect to Design Architect}

The Program Architect provides the project program, planning concepts, building considerations and analysis, and a project budget (Table 14). The information for the program comes from working with the campus project committee to develop the programming and feasibility study, and is available as an electronic document and hard copy. The recommendations, which follow, were developed on two levels-one is a small step up from the current formats toward BIM, and the other utilizes BIM formats.

Table 14. List of Program Architect Information to Provide to Design Architect

\begin{tabular}{|c|c|c|c|}
\hline Program Information & Purpose & $\begin{array}{l}\text { Information } \\
\text { Format }\end{array}$ & $\begin{array}{l}\text { Suggested } \\
\text { Format }\end{array}$ \\
\hline \multicolumn{4}{|l|}{ Program Overview } \\
\hline Executive Summary & Introduction to project and goals & pdf & Word \\
\hline Introduction & $\begin{array}{l}\text { Introduction to campus and project } \\
\text { origination }\end{array}$ & pdf & Word \\
\hline Project Team & $\begin{array}{l}\text { List of participants in previous phase } \\
\text { to understand composition of project } \\
\text { team and contributors }\end{array}$ & pdf & Word \\
\hline \multicolumn{4}{|l|}{ Project Program } \\
\hline Project Goals & $\begin{array}{l}\text { Program, and Building and Site } \\
\text { goals }\end{array}$ & pdf & Word \\
\hline Project Description & Description of spaces & pdf & Word \\
\hline Program Summary & $\begin{array}{l}\text { List of spaces, names, sizes and } \\
\text { number of stations }\end{array}$ & pdf & Excel \\
\hline \multicolumn{4}{|l|}{ Planning Concepts } \\
\hline Site Analysis & $\begin{array}{l}\text { Location, topography, site area, } \\
\text { utilities, circulation }\end{array}$ & pdf & Word \& 3-D \\
\hline Campus Master Plan & $\begin{array}{l}\text { Planning objectives for building } \\
\text { footprint and massing, open space, } \\
\text { integration with campus and } \\
\text { adjacent buildings, pedestrian and } \\
\text { vehicular circulation }\end{array}$ & pdf & Word \& 3-D \\
\hline Building Design & Concept, levels with types of spaces & pdf & Word \& 3-D \\
\hline
\end{tabular}




\begin{tabular}{|c|c|c|c|}
\hline Program Information & Purpose & $\begin{array}{l}\text { Information } \\
\text { Format }\end{array}$ & $\begin{array}{l}\text { Suggested } \\
\text { Format }\end{array}$ \\
\hline \multicolumn{4}{|c|}{ Building Considerations \& Analysis } \\
\hline Codes \& Standards & $\begin{array}{l}\text { Applicable codes, requirements and } \\
\text { standards }\end{array}$ & pdf & Word \& 3-D \\
\hline $\begin{array}{l}\text { Architectural Basis of } \\
\text { Design }\end{array}$ & $\begin{array}{l}\text { Organizational Concept and } \\
\text { massing, modular planning and } \\
\text { feasibility, orientation, materials, } \\
\text { exterior, interior, and technology } \\
\text { infrastructure and equipment }\end{array}$ & pdf & Word \& 3-D \\
\hline Construction Phasing & $\begin{array}{l}\text { Issues to be addressed during } \\
\text { construction }\end{array}$ & pdf & $\begin{array}{l}\text { Word \& } \\
\text { Scheduling }\end{array}$ \\
\hline Sustainability & $\begin{array}{l}\text { CSU requirements, site } \\
\text { considerations, water efficiency, } \\
\text { materials and resources, energy and } \\
\text { Atmosphere, LEED checklist }\end{array}$ & pdf & $\begin{array}{l}\text { Word \& } \\
\text { Excel }\end{array}$ \\
\hline $\begin{array}{l}\text { Landscape Basis of } \\
\text { Design }\end{array}$ & $\begin{array}{l}\text { Functional requirements, master } \\
\text { plan goals }\end{array}$ & pdf & Word \& 3-D \\
\hline Site Utilities & $\begin{array}{l}\text { District Heating and Cooling, storm } \\
\text { water drainage, fire hydrants, gas, } \\
\text { sewer, water, telecommunications, } \\
\text { street lights, SCADA fiberoptic }\end{array}$ & pdf & Word \& 3-D \\
\hline Structural Basis of Design & $\begin{array}{l}\text { Existing structural systems, building } \\
\text { materials, condition }\end{array}$ & pdf & $\begin{array}{l}\text { Word \& } \\
\text { Structural } \\
\text { Analysis }\end{array}$ \\
\hline $\begin{array}{l}\text { Mechanical Basis of } \\
\text { Design }\end{array}$ & $\begin{array}{l}\text { Passive strategies, energy } \\
\text { efficiency, occupant comfort }\end{array}$ & pdf & $\begin{array}{l}\text { Word \& } \\
\text { Mechanical } \\
\text { Analysis }\end{array}$ \\
\hline $\begin{array}{l}\text { Plumbing \& Fire } \\
\text { Protection Basis of } \\
\text { Design }\end{array}$ & $\begin{array}{l}\text { Domestic water service, sanitary } \\
\text { drainage and vent systems, storm } \\
\text { water, fire protection, LEED criteria } \\
\text { and sustainability }\end{array}$ & pdf & $\begin{array}{l}\text { Word \& } \\
\text { Plumbing } \\
\text { Analysis }\end{array}$ \\
\hline Electrical Basis of Design & $\begin{array}{l}\text { Electrical system description, } \\
\text { distribution equipment, minimum bus } \\
\text { sizes, feeder size, method of } \\
\text { distribution, grounding, receptacle } \\
\text { power, electrical associated with } \\
\text { mechanical and plumbing, general } \\
\text { lighting, telecommunication system, } \\
\text { fire alarm system and LEED criteria } \\
\text { and sustainability }\end{array}$ & pdf & $\begin{array}{l}\text { Word \& } \\
\text { Electrical } \\
\text { Analysis }\end{array}$ \\
\hline \multicolumn{4}{|l|}{ Project Budget } \\
\hline Cost Basis of Design & $\begin{array}{l}\text { Cost estimate, inclusions and } \\
\text { exclusions, market conditions }\end{array}$ & pdf & $\begin{array}{l}\text { Word \& } \\
\text { Excel }\end{array}$ \\
\hline \multicolumn{4}{|l|}{ Other Information } \\
\hline Room Data Sheets & $\begin{array}{l}\text { Size, occupants, systems, } \\
\text { equipment and furnishings }\end{array}$ & pdf & 3-D \& Excel \\
\hline $\begin{array}{l}\text { Work Session Agendas \& } \\
\text { Meeting Minutes }\end{array}$ & $\begin{array}{l}\text { Information from Programming } \\
\text { sessions }\end{array}$ & pdf & Word \\
\hline
\end{tabular}

Source: Data adapted from Killefer Flammang "Program." 
Recommendation \#1 - Receive information from consultants in the original software format.

Cal Poly should require programming and feasibility information be delivered in the software formats in which it was developed and assembled. Information in its original format can be shared with others saving the time required to input information into a software program, and may possibly be transferred to other software applications without degradation of the information. This is a small step up from the electronic non editable files, and is noted under "Suggested Format" in Table 14.

Recommendation \#2 - Acquire and utilize a web-based planning program as the repository of information for all phases of the campus projects to aid in developing a collaborative environment.

Cal Poly should establish a goal of developing a collaborative project work environment where an open standard is required, information is stored in a Webaccessible data base (repository of information), and systems are able to talk to each other. According to Kimon Onuma, it is not realistic to "imagine building a Revit model and all its connections." He further notes that many owners "have their own data base of how they configure and operate," but with "an open standard you can start creating systems that talk to each other," handle "complex interconnections," and eliminate many errors and disconnects. ${ }^{14}$

The University should acquire and begin utilizing a web-based software program, such as Onuma Planning Systems (OPS) with an open standard system, that allows users to interact via the Internet, to populate BIM designs with data from simple programs such as Excel and Google Earth, and to contribute designs and information from many different software types integrating it all into a building modeling format.

Firms such as Onuma Inc. have created a specialized business developing tools and engines focusing on helping the owner analyze operational requirements, and perform preliminary analysis before initiating a project. Tools that provide for early planning help the owner make decisions sooner. For instance, the owner 
may analyze operational requirements and develop potential options before deciding to hire a Program Architect. ${ }^{15}$

Onuma sees architects getting involved with the owner much earlier in a project to provide another perspective instead of reacting to what the owner wants. He notes that:

Some owners are looking at ways to change how they even request information from the architects. So instead of having a whole stack of Excel files, or documents, and saying here's the project we are thinking of doing, actually hand them a BIM data file saying here's all the pieces that we're considering using. Provide your planning part . . . back to us in this format. ${ }^{16}$

This repository of information would not be the actual design, estimating, scheduling and analysis software needed to plan, design, construct, maintain and occupy a campus facility. That would still reside with the various project team members. However, the information created by each team member would be added to the repository as the project progresses. In the interim, Cal Poly would need to require the files in their software vendor format, and encourage the use of IFC format software.

Recommendation \#3 - Provide, add to and maintain information for all campus buildings and projects in a web-accessible BIM data base.

To improve upon the information provided by the Program Architect to pass onto the Design Architect, it would be beneficial for the information to be in BIM in its original software configuration so that it can be accessed by the Design Team. For example, if the utility maps were provided in a Revit file, it would be easier for the Design Architect to add to the information. This same desire would apply to the room data sheets and cost estimates. Better yet, if the software utilized could be provided in IFC format, then the information added by the Program Architect would be more accurate and save time that could be devoted to analysis of options and systems. As the project repository of information (BIM) continues to grow, the team members would have access to continue to utilize and add to it (Figure15). 


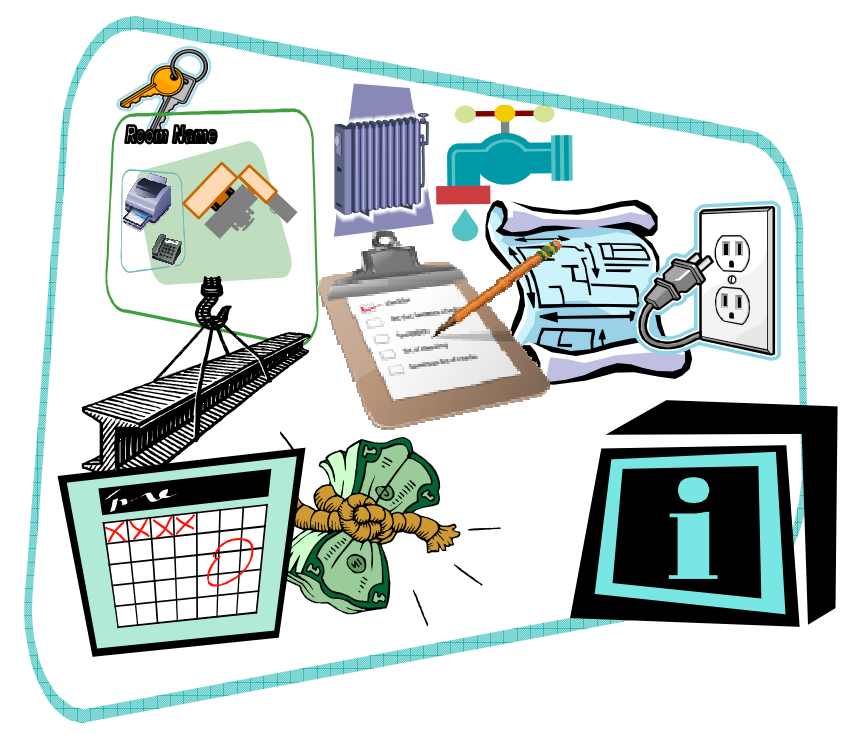

Figure 15. Repository of Information, or BIM. Sources: Concept by Author, and Clip Art from Microsoft Office 2003.

When Brent Pilgrim of Beck Technology, an integrated (design and construction) project services firm, begins the conceptual phase, the team members collaborate to prepare a macro-BIM cost model. Together they visualize and document assumptions about the project. While one can expect the assumptions to change later on, project team members know the assumptions, and the project costing can easily be prepared in-line with those assumptions. As the assumptions change, the costs are adjusted. ${ }^{17}$

Beck Technology has used DProfiler, a conceptual cost estimating BIM application, for the last three years to visualize, estimate and communicate the project information. The costs are so heavily involved in a project that rarely do they have a budget problem. ${ }^{18}$ Tools such as DProfiler in IFC format would allow analysis of building systems, costing (4-D), and construction phasing (5-D) in a more efficient manner saving time and money for all members of the project team. 


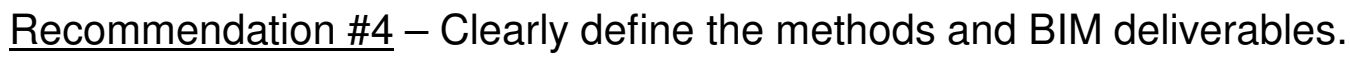

To encourage the implementation of BIM on projects, a list of specific methods and deliverables should be identified and included in the agreements with the Program Architect, Design Architect, and Contractor, including:

1) a requirement to utilize the Integrated Project Delivery approach outlined by the American Institutes of Architects, or the Lean Construction principles used by many construction firms; ${ }^{19}$

2) the software to be utilized by each participant; and

3) a specific list of deliverables.

Rather than asking what BIM capacity a firm has in-house and its number of BIM stations (as is done in the CSU Application for Architectural Prequalification), Cal Poly should take a more active role and clearly define the BIM deliverables desired by the University. Cal Poly should also require that the firms use an integrated project team approach and successfully demonstrate how the software is utilized in developing a project.

${ }^{1}$ Brent Pilgrim, telephone interview by author, (26 November 2008).

${ }^{2}$ Dane Dodd-Hansen, telephone interview by author, (21 November 2008).

${ }^{3}$ Dodd-Hansen.

${ }^{4}$ Kimon Onuma, telephone interview by author, (22 November 2008).

${ }^{5}$ Charles Matta, and Calvin Kam, "The GSA's BIM Pilot Program," http://www.aia.org/SiteObjects/files/gsa.pdf (accessed 16 December 2008).

${ }^{6}$ Matta and Kam.

${ }^{7}$ Matta and Kam.

${ }^{8}$ Matta and Kam.

${ }^{9}$ AIA National / AIA California Council, Integrated Project Delivery: A Guide, version 1, (The American Institute of Architects, 2007), 7.

${ }^{10} \mathrm{AIA} I P D, 7$.

${ }^{11}$ Christopher Pechacek, telephone interview by author, (26 November 2008).

${ }^{12}$ Pechacek.

${ }^{13}$ Onuma.

${ }^{14}$ Onuma.

${ }^{15}$ Onuma.

${ }^{16}$ Onuma. 
${ }^{17}$ Pilgrim.

${ }^{18}$ Pilgrim.

${ }^{19}$ AIA IPD, Appendix-Glossary. 


\section{CHAPTER 4}

Results

\section{Summary}

\section{Future of Industry}

As experts from architects to contractors weigh in with their opinions, each view BIM as the future of the industry with its advantages and challenges through a different lens. For each, BIM offers increasing analysis and accuracy with efficiencies in time and costs.

Kimon Onuma believes that the construction-side of the industry has been ahead in the use of BIM and in more advanced ways because it affects their bottom line. BIM use has been greatly project-focused with collision detection and highly detailed models.

Chris Pechacek believes that the industry members are dissimilar in implementing and using BIM, and sums up the progress thus far:

I think that the subcontractors are leading it. The general contractors are half a step behind. The structural engineers on the design team are much further ahead than the architects. The owners desire it; they want it; they don't understand it. . . . Hopefully, we have a snowball that is heading down the mountain. ${ }^{1}$

Brent Pilgrim predicts that within the next five years the industry will make huge steps forward to being better and more efficient because of BIM tools. His assumptions are based on the adaption rate by architecture firms and other industry firms to the use of Revit, and the suite of products interacting with other products. For instance, he points to Navisworks' benefits and value currently seen by team members during the construction phase. Navisworks allows for viewing 3-D models, simulating 4-D construction schedule, and clash detection. $\mathrm{He}$ anticipates that BIM tools will be the standard in the industry, and in five to ten years, this will translate to a data model that will be used for facilities management as well. ${ }^{2}$ 


\section{Advantages}

Beck Technology is using BIM as a building 3-D communication tool to pull everybody to the same start. ${ }^{3}$ When Beck begins a project at the conceptual phase, the architecture and construction groups meet and perform a macro-BIM cost model as the project is visualized and communicated to everyone. ${ }^{4}$

Onuma, Inc. is able to offer owners a web-based space, building and project management tool to aid in programming and quick analysis of potential projects. This tool can be used throughout the project as a way to gather, contribute and share project information. Sharing data among users is seen as one of the major benefits of BIM.

BIM is being widely adopted in the construction industry. The McGraw-Hill reports that "over $50 \%$ of each survey segment-architect, engineers, contractors, and owners-[are] utilizing the tools at moderate levels or higher." Those tracking their return on investment have see improvements of 100 percent to 1000 percent. Contractors in the two case studies conducted by McGraw-Hill have seen a return on investment of 300 to 500 percent. As firms become more experienced with the use of BIM data, they are more able to leverage data analysis and improve upon their bottom line.

\section{Challenges}

Kimon Onuma states that the biggest challenge is the "cultural shift." For example, he notes:

You can have a system that works right before your eyes, but the biggest resistance that you have is entrenched ways of doing things. If a company or group [has been] doing things a certain way for the last 30 years and they are making money ... I see great resistance. ${ }^{6}$

Onuma explains that the resistance exists because the perception is that it will cut into the company's contract and profit even when shown that a change will take one-tenth the time. He gives this observation from his experience in encouraging others to embrace BIM: 
It's more advantageous for that group to keep doing it inefficiently because that's tied to people working on it and putting hours into it. That goes all the way through contracting and everything. So there is a lot of confusion when these new technologies come around to wanting to make that shift. You can't do it half way. If you start doing things half here and half there, it sometimes works, but if you don't have buy-in from the top down, it doesn't work. $^{7}$

People tend to be focused on producing drawings rather than the information in BIM. Kimon Onuma acknowledges that firms are often "document focused," and even though his firm focuses on the project, they also focus on the system where he sees immense opportunities. ${ }^{8}$ There are Architects who want to become more competitive and efficient internally, and offer clients a different, new specialty based on BIM tools.

Chris Pechacek believes that the biggest winners would be the facility managers, but BIM applications for operating and maintaining facilities are deficient:

I think the injustice is that the facilities management applications have not kept up. So when you look at what is the biggest benefit of having all this information and knowledge, it is for the owners to be able to use that [BIM] to manage their facilities. Currently, owners can do portfolio and asset property management, but not much more software is available. ${ }^{9}$

Initial costs and learning curves may be drawbacks to design firms and this has been the reason most have been slow to adopt software programs such as Revit and ArchiCAD observes Dane Dodd-Hansen. While contractors can save time and money right away, design firms won't see the results for a while. ${ }^{10}$

When architects are busy, they don't have time to try new software and adopt new project processes and procedures. Many times in the past, Onuma has tried to get architects interested in working with BIM and OPS, but are told "we don't have the time to even consider this." 11

In a survey of architects, engineers, contractors and owners conducted between June 18 and August 8, 2008, by McGraw-Hill Construction, challenges to adoption of BIM included training, costs of software and hardware, staff buy-in and other factors of less frequent concern, such as lack of external incentives, potential risk of losing intellectual property, and liability issues. ${ }^{12}$ 


\section{Significance for Cal Poly and the CSU}

Cal Poly and the CSU should not wait for BIM to become the industry standard and should take a major role in developing ways to incorporate it now. Onuma, Inc. has been using BIM for years to produce the construction documents their way without telling their clients and consultants. Kimon Onuma explains their approach:

We have to identify where all the stake holders have comfort; what their comfort levels [are] with working with the technology, and not push it too far; take baby steps. You can be ahead of the curve by using new processes and new tools that they are not even aware of. ${ }^{13}$

The University is already using BIM and also may not be aware of it. Cal Poly maintains Excel spreadsheets populated with space data, including size and function. Information for the newer buildings is available in CAD files, while older building plans have been scanned and are available in electronic format. Cal Poly also has Campus Standards in electronic format for use by project managers and consultants. This is all information appropriate for BIM. Cal Poly and its consultants share information by posting on a website. Cost estimates and project budgets are produced and shared electronically.

The next step for Cal Poly is to begin collecting all this building information into a database where it can be easily accessed, updated and shared as a project progresses. BIM is not Revit or ArchiCAD; it is so much more. It is all the project information from conception through decommissioning. It is the "Building Information Model."

\section{Advice for Future Study}

\section{Rocks and Boulders}

BIM is less about software and more about process. To fully understand the Building Information Model is at best a difficult endeavor. However, one can begin by looking at obstacles and create a plan to conquer each one. Chris Pechacek recommends defining what is of value for a project, and using BIM to eliminate disconnects. ${ }^{14}$ For instance, on the Center for Science the architect 
was not filling in the gaps for the cost estimators who were forced into making assumptions about the materials and systems. Evaluating the obstacles that prevented the architect from filling in the gaps sooner would be beneficial to the design process. In conquering the constraints on a project, Pechacek suggests getting the big rocks out of the way first and cautions to watch for the small rocks as one will usually "trip over the small rocks" while avoiding "the boulders." 15

\section{Study Areas}

Building information modeling is still a new approach for the construction industry. It is driving changes in how people work, and opening up opportunities for every aspect of the building planning, design, construction, facility management and deconstruction. Each segment of the industry will benefit in numerous ways from BIM. Its potential is only beginning to be explored and promises to be vast. The following recommendations for areas of further study are based on concerns being raised in the industry in implementing building information modeling.

Role of Educators at Colleges and Universities

How are colleges and universities preparing students for a future of BIM? What role should they play, and what is the best way to prepare future graduates?

\section{Industry Standards}

What industry standards are being developed to enable the industry to work with BIM? Are there additional areas not yet covered such as sustainability?

Changes to Owner-Architect-Contractor Agreements

What changes are industry organizations and building owners recommending? Owners should determine and make their BIM needs a part of the agreement. Architects, consultants, contractors, subcontractors and suppliers each will have BIM needs, and industry organizations, such as American General Contractors (AGC) and AIA, have already begun making recommendations.

Overcoming Obstacles to BIM 
How are organizations overcoming the obstacles in the implementation of BIM? What difficulties have they encountered, and how can others build upon the successes?

Implementing Lean Principles for Planning and Feasibility Studies

What benefits can be derived for Planning and Feasibility from studying and implementing Lean Principles?

\section{Conclusion}

During the one year time period spent researching BIM for this thesis, its potential impacts on the future of the construction industry, and how Cal Poly and CSU might begin to take advantage of it, the BIM movement has been gathering momentum. As this thesis was being finalized, CSI issued an announcement on their website that McGraw-Hill Construction had just released a report showing the growing enthusiasm and potential for intensify usage in 2009 of BIM. This statement from the CSI announcement succinctly states the direction of the construction industry:

"Users plan to significantly increase their investment in BIM in 2009 to realize greater productivity, improved communications, and a competitive edge."16

CSU and Cal Poly have an opportunity to begin shaping the use of BIM for university projects. Rather than waiting to see what firms can offer in relationship to BIM, Cal Poly should take the approach of determining the information needed to program, design, construct, operate and maintain buildings on the campus in a BIM format, and include the requirements for consultants in their contracts. Program architects should provide information needed by campus, the CSU and the design architect to meet the campus needs. The design architect should provide information needed by the contractor to construct a facility; and finally, the contractor should provide information needed by the campus to operate and maintain a facility.

As the construction industry moves toward integrated project development, campus planning, design and construction will change rapidly. The opportunities 
for utilization of BIM continue to increase as the industry realizes additional facets and benefits of the information aspects, the "I" for Information in BIM.

${ }^{1}$ Christopher Pechacek, telephone interview by author, (26 November 2008).

${ }^{2}$ Brent Pilgrim, telephone interview by author, (26 November 2008).

${ }^{3}$ Pilgrim.

${ }^{4}$ Pilgrim.

${ }^{5}$ McGraw-Hill Construction, "SmartMarket Report on Building Information Modeling: Transforming Design and Construction to Achieve Greater Industry Productivity," (McGraw-Hill Construction, 2008) http://www.csinet.org/s_csi/sec.asp?TRACKID=\&CID=30\&DID=16527 (accessed 17 December 2008), 2

${ }^{6}$ Kimon Onuma, telephone interview by author, (22 November 2008).

${ }^{7}$ Onuma.

${ }^{8}$ Onuma.

${ }^{9}$ Pechacek.

${ }^{10}$ Dane Dodd-Hansen, telephone interview by author, (21 November 2008).

${ }^{11}$ Onuma.

${ }^{12}$ McGraw-Hill, 9.

${ }^{13}$ Onuma.

${ }^{14}$ Pechacek.

${ }^{15}$ Pechacek.

${ }^{16}$ The Construction Specifications Institute, "BIM Report Shows Growing Demand for Digital Models Training," http://www.csinet.org/s_csi/sec.asp?TRACKID=\&CID=2473\&DID=16527 (accessed 17 December 2008). 


\section{BIBLIOGRAPHY}

AIA National / AIA California Council. Integrated Project Delivery: A Guide, version 1. The American Institute of Architects, 2007.

Anderson, Eric and Mark Wagner. "Is the $A / E / C$ industry ready for process reform?" DJC.COM (October 25, 2007). http://www.djc.com/news/ae/ 11194203.html (accessed 5 February 2008).

Beck Technology. "Examples - Two Alliance Center." http://www.becktechnology.com/examples.asp (accessed 6 January 2009).

"BIM adoption accelerating, owners study finds." Building Design and Construction (13 November 2007). http://www.bdcnetwork.com/article/CA6500734.html (accessed11 December 2007).

California Polytechnic State University. "Request for Proposal - Construction Manager at Risk with Guaranteed Maximum Price - Center for Science RFP MAJ 06-310, Article B - Information for Proposers." 15 January 2007.

The California State University. "Calculation of Space Requirements for Instructional Projects, Form CPDC 2-3," under "Major Capital Outlay Forms," http://www.calstate.edu/cpdc/Facilities Planning/forms.shtml (accessed 27 May 2008).

---. "Major Capital Outlay Forms." http://www.calstate.edu/cpdc/ Facilities Planning/majorcapoutlay.shtml (accessed 8 December 2008).

---. "State University Administrative Manual (SUAM)." http://www.calstate.edu/ CPDC/SUAM/ (accessed 13 May 2008).

---. "SUAM, Section I - Capital Outlay and Public Works Contracts, Sections 9000-9004." (Rev 11.02) http://www.calstate.edu/CPDC/SUAM/ SUAM9000-9004.pdf (accessed 13 May 2008).

---. "SUAM, Section II - Physical Master Plan and Off-Campus Centers, Sections 9007-9014." (Rev 10.02) http://www.calstate.edu/CPDC/SUAM/ SUAM9007-9014.pdf (accessed 13 May 2008).

---. "SUAM, Section III - Land Use Planning and Environmental Review, Sections 9015-9020." (Rev 9.06) http://www.calstate.edu/CPDC/SUAM/ SUAM9015-9020.pdf (accessed 13 May 2008).

---. "SUAM, Section IV: Fiscal Resources for Campus Development, Section 9025-9040." (Rev 12.02) http://www.calstate.edu/CPDC/SUAM/ SUAM9025-9040.pdf (accessed 13 May 2008).

---. "SUAM, Section V: Measurement Devices for Physical Planning, Sections 9045-9050." (Rev 12.02) Online. Internet. http://www.calstate.edu/ CPDC/SUAM/SUAM9045-9050.pdf (accessed 13 May 2008). 
---. "SUAM, Section VI: Standards for Campus Development Programs, Sections 9060-9079." (Rev 12.02) http://www.calstate.edu/CPDC/SUAM/ SUAM9060-9079.pdf (accessed 13 May 2008).

---. "SUAM, Section VII: Five-Year Capital Improvement Program Procedures and Formats for Capital Outlay Submission, Sections 9100-9114." (Rev 4.03) http://www.calstate.edu/CPDC/SUAM/SUAM9100-9114.pdf 13 May 2008).

(accessed

---. "SUAM, Section IX: Energy Conservation and Utilities Management, Section 9170." (Rev 4.02) http://www.calstate.edu/CPDC/SUAM/ SUAM9170.pdf (accessed 13 May 2008).

---. "SUAM, Section X: Professional Services For Campus Development Public Works-Related Service Agreements, Sections 9200-9212." (Rev 07.06) http://www.calstate.edu/CPDC/SUAM/SUAM9200-9212.pdf (accessed 13 May 2008).

---. "SUAM, Section XI: Project Plan Development for Major Capital construction Projects, Sections 9230-9237." (Rev 5.04) http://www.calstate.edu/CPDC/ SUAM/SUAM9200-9212.pdf (accessed 13 May 2008).

---. "SUAM, Appendix B: Facilities Planning." http://www.calstate.edu/cpdc/suam/ Appendices/Appendix B.shtml (accessed 20 May 2008).

Capital Outlay Budget Change Proposal, Cal Poly, San Luis Obispo. 2002/03 State and Non-State Capital Outlay Program. November 2000.

Capital Outlay Budget Change Proposal, Cal Poly, San Luis Obispo. 2004/05 State and Non-State Capital Outlay Program. November 2003.

Capital Outlay Budget Change Proposal, Cal Poly, San Luis Obispo. 2005/06 State and Non-State Capital Outlay Program. November 2004.

Capital Outlay Budget Change Proposal, Cal Poly, San Luis Obispo. 2006/07 State and Non-State Capital Outlay Program. November 2005.

Capital Outlay Budget Change Proposal, Cal Poly, San Luis Obispo. 2007/08 State and Non-State Capital Outlay Program. November 2006.

Capital Outlay Budget Change Proposal, Cal Poly, San Luis Obispo. 2008/09 State and Non-State Capital Outlay Program. November 2007.

Capital Outlay Budget Change Proposal, Cal Poly, San Luis Obispo. 2009/10 State and Non-State Capital Outlay Program. November 2008.

The Construction Specifications Institute. The Project Resource Manual-CSI Manual of Practice, Fifth Edition. New York: McGraw-Hill, 2005.

---. UniFormat - A Uniform Classification of Construction Systems and Assemblies. The Construction Specifications Institute, Third Printing January 2000. 
---. "BIM Report Shows Growing Demand for Digital Models, Training." http://www.csinet.org/s_csi/sec.asp?TRACKID=\&CID=2473\&DID=16527 (accessed 17 December 2008).

Fallon, Kristine K. and Mark E. Palmer. General Buildings Information Handover Guide: Principles, Methodology and Case Studies, NISTIR 7417. U.S. Department of Commerce National Institute of Standards and Technology, August 2007.

Frary, I.T. Thomas Jefferson Architect and Builder. Richmond: Garrett and Massie, Incorporated, 1939.

Gilbane. "Schematic Design Estimate - California Polytechnic State University Center for Science and Mathematics, San Luis Obispo, California." 11 July 2007.

---. "Design Development Estimate - 100 Percent - California Polytechnic State University Center for Science and Mathematics, San Luis Obispo, California." 29 January 2008.

---. "Construction Documents Estimate - 50 Percent - California Polytechnic State University Center for Science and Mathematics, San Luis Obispo, California." 25 July 2008.

Harris, Cyril M. Dictionary of Architecture and Construction, $4^{\text {th }}$ ed. New York: McGraw-Hill, 2006.

Jernigan, Finith. BIG BIM little bim. Salisbury: 4Site Press, 2007.

Khemlani, Lachmi. "The IFC Building Model: A Look Under the Hood." AECbytes (30 March 2004). http://www.aecbytes.com/feature/2004/IFCmodel.html (accessed 13 February 2008).

---. "Top Criteria for BIM Solutions: AECbytes Survey Results." AECbytes (10 October 2007). http://www.aecbytes.com/feature/2007/BIMSurveyReport. html (accessed 12 October 2007).

Kieran, Stephan, and James Timberlake. Refabricating Architecture: How Manufacturing Methodologies Are Poised to Transform Building Construction. New York: McGraw-Hill, 2004.

Killefer Flammang Architects and Shepley Bulfinch. Academic Center and Library - Programming and Feasibility Study. California Polytechnic State University, San Luis Obispo, 15 October 2008.

Kim, W. Chan, and Renée Mauborgne. Blue Ocean Strategy: How to Create Uncontested Market Space and Make the Competition Irrelevant. Boston: Harvard Business School Press, 2005.

Matta, Charles and Calvin Kam. "The GSA's BIM Pilot Program." (2005). http://www.aia.org/SiteObjects/files/gsa.pdf (accessed 16 December 2008). 
McGraw-Hill Construction. "SmartMarket Report on Building Information Modeling: Transforming Design and Construction to Achieve Greater Industry Productivity." McGraw-Hill Construction (2008). http://www.csinet.org/s_csi/ sec.asp?TRACKID=\&CID=30\&DID=16527 (accessed 17 December 2008).

National Institute of Building Sciences (NIBS), Facility Information Council (FIC). National Building Information Modeling Standard, Version 1 - Part 1: Overview, Principles, and Methodologies, 2007.

Onuma, Kimon and Yong Ku Kim. "BIMStorm LAX - Overview and Players' Perspectives." (5 February 2008). Webinar.

Onuma, Kimon. Forward. BIG BIM little bim. By Finith Jernigan. BookSurge LLC and Design Atlantic Ltd, 2007.

Peña, William, Steven Parshall, and Kevin Kelly. Problem Seeking: An Architectural Programming Primer, $3^{\text {rd }}$ ed. Washington: AIA Press, 1987.

Prather, Gary. "INSIGHT: Building Information Modeling: The Wave of the Future?" ArchNewsNow.com (18 September 2007). http://www.archnewsnow.com/ features/Feature234.htm (accessed 20 September 2007).

RRM Design Group. The Center for Science: Program Document and Feasibility Study. California Polytechnic State University, San Luis Obispo, October 2006.

Rousseau, Bryant. "The ArchRecord Interview: SOM's Carl Galioto and Paul Seletsky on BIM." Architectural Record (2008). http://archrecord. construction.com/features/interviews/0803SOM BIM/0803 BIM-1.asp (accessed 6 March 2008).

Rundell, Rick. "1-2-3 Revit: BIM and Visualization, Part 1." Cadalyst AEC (1 July 2007). http://aec.cadalyst.com/aec/Column\%3A+1-2-3+Revit/1-2-3-RevitBIM-and-Visualization-Part- 1/ArticleStandard/Article/detail/438584?context Categoryld=6569 (accessed 26 November 2007).

Tardif, Michael. "Architect Creates Design Synthesis Software." AlArchitect - The American Institute of Architects, Volume14 (17 August 2007). http://www.aia.org/aiarchitect/thisweek07/0817/0817rc_face.cfm (accessed 18 February 2008).

Thorton Tomasetti. http://www.thorntontomasetti.com/project_delivery.php (accessed 6 January 2009).

Webb, Bailey. "BIM dream becoming a reality." Atlanta Business Chronicle (10 December 2008). http://www.bizjournals.com/atlanta/stories/2007/07/09/ focus7.html (assessed 10 January 2009).

Yoders, Jeff. "Further Down the Merry Road to BIM." Building Design and Construction (1 November 2007). http://www.bdcnetwork.com/article/ CA6501465.html (assessed 11 December 2007). 


\section{APPENDICES}

\section{$\underline{A-G l o s s a r y}$}

\section{2-D}

A geometric model of an object; a two-dimensional figure on one plane. Often used as components of a 3-D model.

\section{3-D}

A geometric model having three dimensions (width, length, and depth).

4-D

Cost estimating information usually tied to a 3-D model.

\section{5-D}

Scheduling information usually tied to a 3-D model.

\section{Building Information Model}

A Building Information Model, (BIM) is a digital representation of physical and functional characteristics of a facility. As such it serves as a shared knowledge resource for information about a facility forming a reliable basis for decisions during its lifecycle from inception onward. A basis premise of BIM is collaboration by different stakeholders at different phases of the life cycle of a facility to insert, extract, update or modify information in the BIM to support and reflect the roles of that stakeholder. The BIM is a shared digital representation founded on open standards for interoperability.

\section{Construction Documents Phase}

Sets forth, in detail, all aspects of project design, function, and construction. Documents are used for estimating the cost of the project, securing bids for its construction, and directing the contractor during the construction period. Documents include detailed construction drawings and materials and building systems specifications.

Reference: http://www.calstate.edu/CPDC/SUAM/SUAM9230-9237.pd, SUAM 9235 


\section{Cost Model}

A breakdown of the construction and project budget into detailed "cost targets." The construction budget is developed in both a detailed Component(s) based format and a CSI based format based on the project's goals, detailed program and performance requirements. The cost targets are developed collaboratively by the integrated team prior to commencing the conceptualization phase of the project process. The structure provides the benchmark for the team to support continuous cost management as the project progresses to ensure that it will be completed within the targeted budget.

\section{CSI UniFormat}

UniFormat, a publication of CSI and CSC, is the Uniform Classification System for organizing preliminary construction information into a standard order or sequence on the basis of functional elements. Functional elements often referred to as systems or assemblies, are major components common to most buildings that usually perform a given function regardless of the design specifications, construction method, or materials used. UniFormat users can easily understand and compare information since it is linked to a standardized elemental classification structure. The use of UniFormat can provide consistent comparable data across an entire building life cycle. The use of its elemental framework reduces the time and cost of evaluating alternatives in the early design stages of a project, assuring faster and more accurate economic analysis of alternative design decisions.

Website: http://www.csinet.org/s csi/sec.asp?CID=1379\&DID=11342

\section{Design Development Phase}

Confirms or adjusts all aspects of the schematic plans (exterior design, mechanical and electrical systems, telecommunications system, structural systems, area arrangements, foundation plans, etc. Documents include plans, outline specifications and cost estimates developed in further detail than schematic documents.

Reference: http://www.calstate.edu/CPDC/SUAM/SUAM9230-9237.pdf, SUAM 9234

\section{DProfiler}

DProfiler, developed by Beck Technology, is a macro Building Information Modeling (BIM) program, integrating 3D modeling with conceptual cost estimating, integrated energy analysis, and export capabilities. The platform is aimed at reducing rework due to late-stage design changes.

Website: http://www.beck-technology.com/index.asp 


\section{GIS}

A geographic information system (GIS) integrates hardware, software, and data for capturing, managing, analyzing, and displaying all forms of geographically referenced information. GIS allows for an individual to view, understand, question, interpret, and visualize data in many ways that reveal relationships, patterns, and trends in the form of maps, globes, reports, and charts.

Website: http://www.gis.com/

\section{Integrated Project Coordinator}

An individual responsible for overall facilitation, coordination and direction of the integrated team. This role may or may not shift among members of the team depending on delivery model and project phase. Leadership and consensus building skills are critical to this role. In some instances, this role may be filled by an outside party.

\section{Lean Construction}

Lean construction is a translation and adaption of lean manufacturing principles and practices to the end-to-end design and construction process. Unlike manufacturing, construction is a project based-production process. Lean construction is concerned with the holistic pursuit of concurrent and continuous improvements in all dimensions of the built and natural environment: design, construction, activation, maintenance, salvaging, and recycling. This approach tries to manage and improve construction processes with minimum cost and maximum value by considering customer needs.

Website: http://en.wikipedia.org/wiki/Lean_Construction

\section{Key Supporting Participant}

A person or organization whose contribution is critically necessary to achieve project goals but is not a primary participant.

\section{Integration}

The coming together of primary participations (which could include owner, design, constructor, design consultants, and trade contractors, key systems suppliers, etc.) at the beginning of a project, for the purpose of designing and constructing the project together as a team.

\section{Navisworks ${ }^{\circledR}$}

Software from Autodesk ${ }^{\circledR}$ to help control, collaborate and aggregate information on project models for viewing and analyzing digital information. Features allow navigation and exploration of design, identification, inspection, and reporting of potential interferences in a 3-D project model.

Website:http://usa.autodesk.com/adsk/servlet/index?id=10571060\&site/D=12311 2 


\section{Open Interoperability Standards}

Non-proprietary protocols and data structures that support the exchange or joint use of digital information by different software tools.

\section{ONUMA Planning System ${ }^{\mathrm{TM}}$ (OPS)}

A web-enabled planning, programming and project system developed by Onuma, Inc.

Website: http://www.onuma.com/products/OnumaPlanningSystem.php

\section{Primary Participant}

Core group of team members involved in and responsible for the project from inception through completion.

\section{Project Delivery Methods}

"Project delivery is the contractual relationships between the owner, architect/engineer, contractor, and the management services utilized to design and construction a project. Project delivery methods include design-bid build, design-negotiate-build, design-build, construction manager, or owner-build. Each delivery method can have variations in types of contract payment (such as lump sum, unit price, and cost-plus), scheduling (such as fast-track), and number of contracts (such as single or multiple-prime contracts.)"

Reference: The Construction Specifications Institute. The Project Resource Manual-CSI Manual of Practice, Fifth Edition. New York: McGraw-Hill, 2005; 3.1.

\section{Project Phases}

Development of a facility requires a number of project steps or phases from initial project conception through occupancy. Typical project stages in sequence are Programming, Schematic Design, Design Development, Construction Documents, Bidding or Negotiations, Construction, and Occupancy.

Reference: The Construction Specifications Institute. The Project Resource Manual-CSI Manual of Practice, Fifth Edition. New York: McGraw-Hill, 2005.

\section{Reverse Phase Scheduling}

Phase scheduling that maximizes value generation, is understood and supported by everyone involved, defines specific handoffs between work groups, and is developed working backwards from the completion date incorporating interim milestones.

Website: $h$ ttp://p2sl.berkeley.edu/2008-04-30/1\%20-\%20Ballard\%20-

\%20Phase\%20Scheduling.ppt\#271,11,Phase Scheduling Process (accessed 17 December 2008) 


\section{Revit ${ }^{\circledR}$}

Building design software for building information modeling (BIM). Changes are automatically coordinated throughout a project. The software allows for quick and easy changes to major compositional elements, to create comprehensive design proposals, and to view ideas on the fly with 3-D views.

Website:

http://usa.autodesk.com/adsk/servlet/index?id=3781831\&sitelD=123112

\section{Schematic Design Phase}

Interprets the project requirements to show relationship of the facility to the site, other buildings, and the campus; exterior design of the facility; relationship of interior areas; materials to be used in construction; types of structural, mechanical, electrical, and telecommunication systems to be utilized; construction cost; and life cycle cost analysis. Documents include drawings, outline specifications and cost estimates.

Reference: http://www.calstate.edu/CPDC/SUAM/SUAM9230-9237.pdf SUAM 9233

\section{Solibri}

Solibri, Inc. develops and provides software that automates the BIM model checking, design review, analysis and code checking process.

Website: http://www.solibri.com/

\section{Vision Statement}

A vision statement outlines what the project wants to be. It concentrates on the future, is a source of inspiration, and provides clear decision-making criteria. 


\section{B - CSU CPDC FORM}

\section{CPDC 2-7}

\section{Form used by CSU campuses to prepare and submit proposed budget for approval.}

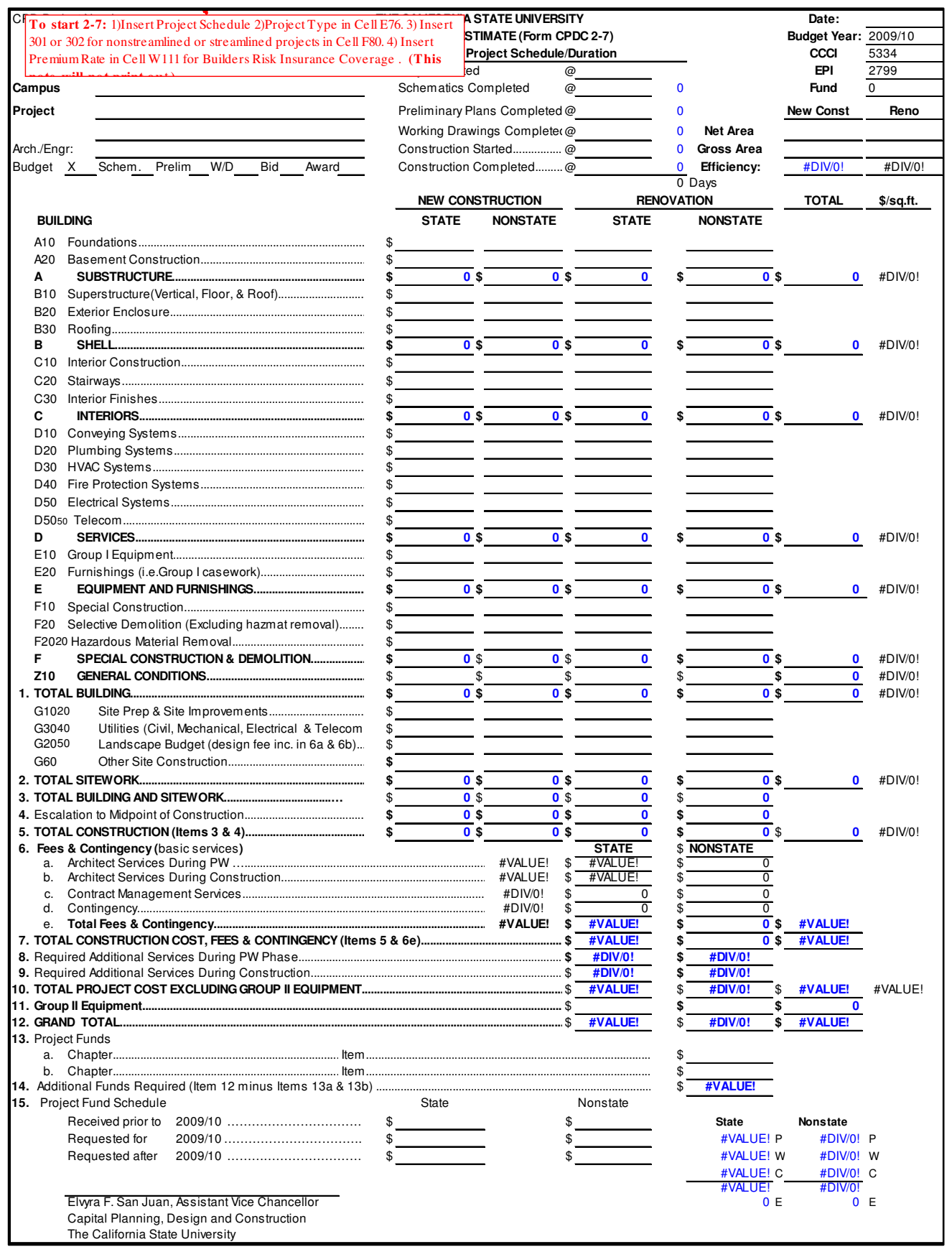

